\title{
A revised representation of urea and ammonia nitrogen recycling and use in the Molly cow model
}

\author{
Meng M. Li, ${ }^{1}$ E. C. Titgemeyer, ${ }^{2}$ and Mark D. Hanigan ${ }^{1 *}$ \\ ${ }^{1}$ Department of Dairy Science, Virginia Polytechnic Institute and State University, Blacksburg 24061 \\ ${ }^{2}$ Department of Animal Sciences and Industry, Kansas State University, Manhattan 66506-1600
}

\begin{abstract}
Accurately predicting nitrogen $(\mathrm{N})$ digestion, absorption, and metabolism will allow formulation of diets that more closely match true animal needs from a broad range of feeds, thereby allowing efficiency of $\mathrm{N}$ utilization and profit to be maximized. The objectives of this study were to advance representations of $\mathrm{N}$ recycling between blood and the gut and urinary $\mathrm{N}$ excretion in the Molly cow model. The current work includes enhancements (1) representing ammonia passage to the small intestine; (2) deriving parameters defining urea synthesis and ruminal urea entry rates; (3) adding representations of intestinal urea entry, microbial protein synthesis in the hindgut, and fecal urea- $\mathrm{N}$ excretion; and (4) altering existing urinary $\mathrm{N}$ excretion equations to scale with body weight and adding purine derivatives as a component of urinary $\mathrm{N}$ excretion. After the modifications, prediction errors for ruminal outflows of total $\mathrm{N}$, microbial $\mathrm{N}$, and nonammonia, nonmicrobial $\mathrm{N}$ were $29.8,32.3$, and $26.2 \%$ of the respective observed mean values. Prediction errors of each were approximately 7 percentage units lower than the corresponding values before model modifications and fitting due primarily to decreased slope bias. The revised model predicted ruminal ammonia and blood urea concentrations with substantially decreased overall error and reductions in slope and mean bias. Prediction errors for gut urea-N entry were decreased from 70.5 to $26.7 \%$, which was also a substantial improvement. Adding purine derivatives to urinary $\mathrm{N}$ predictions improved the accuracy of predictions of urinary $\mathrm{N}$ output. However, urinary urea-N excretion remains poorly predicted with $69.0 \%$ prediction errors, due mostly to overestimated urea- $\mathrm{N}$ entry rates. Adding representations of undigested microbial nucleic acids, microbial protein synthesized in the hindgut, and urea- $\mathrm{N}$ excretion in feces decreased prediction
\end{abstract}

Received November 5, 2018.

Accepted January 27, 2019.

*Corresponding author: mhanigan@vt.edu errors for fecal $\mathrm{N}$ excretion from 21.1 to $17.1 \%$. The revised model predicts that urea- $\mathrm{N}$ entry into blood accounts for approximately $64 \%$ of dietary $\mathrm{N}$ intake, of which $64 \%$ is recycled to the gut lumen. Between 48 and $67 \%$ of the urea recycled to the gut flows into the rumen largely depending on diet, which accounts for 29 to $54 \%$ of total ruminal ammonia production, and 65 to $76 \%$ of this ammonia- $\mathrm{N}$ is captured in microbial protein, which represents $17 \%$ of $\mathrm{N}$ intake. Based on model simulations, feeding a diet with moderately low crude protein and high rumen-undegradable protein could increase apparent ruminal N efficiency by $20 \%$.

Key words: utilization efficiency, model, nitrogen, Molly cow model

\section{INTRODUCTION}

The ability to recycle urea- $\mathrm{N}$ to the rumen represents an evolutionary advantage of ruminants, allowing them to better utilize N, especially during periods of dietary protein deficiency. Many current models are empirical and based on data fits, so the level of aggregation of these models generally does not allow detailed analyses of specific metabolic reactions. Baldwin and coworkers included concepts and essential features of $\mathrm{N}$ metabolism in a mathematical model of the dairy cow named Molly (Baldwin et al., 1987a,b,c). Molly is a dynamic and mechanistic model that has potentially greater flexibility and functionality when evaluating different management strategies and feeding practices being considered for implementation. However, the added complexity also increases the difficulty of model parameterization. Based on the original model structure, Hanigan et al. (2013) reported biased predictions of ruminal ammonia concentrations and microbial N outflow, and Li et al. (2018) observed high proportions of ruminal ammonia and blood urea prediction errors due to slope bias. The latter work identified improper representations of urinary urea- $\mathrm{N}$ excretion and urea-N cycling between blood and the rumen as the primary drivers of the ammonia and blood urea prediction errors. 
To address such existing model problems, measurements of gut urea- $\mathrm{N}$ entry and urinary urea- $\mathrm{N}$ excretion rates are necessary to uniquely define $\mathrm{N}$ recycling between the rumen and blood and to define urea balance. Lobley et al. (2000) described a double-labeled urea approach to measure urea kinetics in ruminants, and developed a steady-state, mass balance model to estimate flux rates. The application of this approach has resulted in the generation of a significant number of flux observations in cattle in the last $20 \mathrm{yr}$, which can be used to examine model assumptions and address potential errors in the model.

The objectives of this study were to update the representations of $\mathrm{N}$ cycling across the gut wall, fecal $\mathrm{N}$ excretion, and urinary $\mathrm{N}$ excretion in the Molly model to more closely reflect the underlying biology, and to evaluate model prediction accuracy with respect to $\mathrm{N}$ and urea kinetics. The work included (1) representing ammonia passage to the small intestine; (2) deriving parameters defining urea synthesis and ruminal urea entry rates; (3) adding representations of intestinal urea entry rate, microbial protein synthesis in the hindgut, and fecal ammonia excretion derived from blood urea; and (4) altering the existing urinary $\mathrm{N}$ excretion equations to scale with BW and adding purine derivatives as a component of urinary $\mathrm{N}$ excretion. We hypothesized that these updates would result in robust improvements in predictions of ruminal $\mathrm{N}$ cycling, microbial outflow from the rumen, and urinary $\mathrm{N}$ excretion.

\section{MATERIALS AND METHODS}

\section{Data Collection}

Observations of total urea entry, gut urea entry, and urinary urea elimination rates were collected from 21 published papers (Archibeque et al., 2001, 2002; Ruiz et al., 2002; Marini and Van Amburgh, 2003; Gozho et al., 2008; Wickersham et al., 2008, 2009a,b; Brake et al., 2010, 2011; Ouellet et al., 2010; Bailey et al., 2012a,b; Titgemeyer et al., 2012; Chibisa and Mutsvangwa, 2013; Davies et al., 2013; Spek et al., 2013; Recktenwald et al., 2014; Holder et al., 2015; Batista et al., 2016; Mutsvangwa et al., 2016) representing 96 treatment means. The only selection criterion was that the work was conducted in cattle and used the doublelabeled urea approach to measure urea kinetics. Nine of the studies were conducted using dairy cattle and 12 studies were conducted using beef cattle. The observed data are summarized in Table 1.

Table 1. A summary of observed nutrient intake, ruminal metabolism, ruminal $\mathrm{N}$ outflow, and urea transfers from the meta-data

\begin{tabular}{|c|c|c|c|c|c|}
\hline Item & $\mathrm{N}$ & Mean & SD & Minimum & Maximum \\
\hline $\mathrm{BW}, \mathrm{kg}$ & 96 & 401.3 & 209.8 & 139.0 & 768.0 \\
\hline \multicolumn{6}{|l|}{ Intake, $\mathrm{kg} / \mathrm{d}$} \\
\hline $\mathrm{DM}$ & 96 & 10.9 & 8.5 & 2.9 & 28.7 \\
\hline $\mathrm{OM}$ & 57 & 8.0 & 7.3 & 2.7 & 26.9 \\
\hline $\mathrm{ADF}$ & 17 & 3.5 & 2.2 & 0.9 & 6.3 \\
\hline $\mathrm{NDF}$ & 12 & 7.9 & 2.6 & 4.3 & 10.1 \\
\hline Starch & 13 & 3.9 & 0.8 & 2.9 & 5.6 \\
\hline Nitrogen & 58 & 0.3 & 0.3 & 0.1 & 0.8 \\
\hline \multicolumn{6}{|l|}{ Rumen fermentation } \\
\hline $\mathrm{pH}$ & 54 & 6.2 & 0.3 & 5.6 & 6.9 \\
\hline Ammonia, mM & 63 & 5.6 & 4.0 & 0.1 & 15.9 \\
\hline Total VFA, mM & 50 & 96.8 & 25.2 & 52.2 & 143.3 \\
\hline Acetate, $\%$ of VFA & 43 & 68.6 & 9.5 & 41.2 & 90.0 \\
\hline Propionate, $\%$ of VFA & 42 & 20.8 & 8.0 & 12.0 & 46.5 \\
\hline Butyrate, $\%$ of VFA & 43 & 9.6 & 3.4 & 5.3 & 19.0 \\
\hline \multicolumn{6}{|l|}{ Ruminal N outflow, $\mathrm{g} / \mathrm{d}$} \\
\hline Total N & 38 & 210.2 & 232.1 & 40.8 & 967.0 \\
\hline Microbial N & 38 & 136.7 & 156.1 & 25.3 & 651.0 \\
\hline Nonammonia, nonmicrobial N & 30 & 89.2 & 76.0 & 15.3 & 281.0 \\
\hline \multicolumn{6}{|l|}{$\mathrm{N}$ metabolism } \\
\hline BUN, mg/dL & 81 & 10.4 & 5.9 & 0.7 & 27.0 \\
\hline BUN entry, g/d & 96 & 214.1 & 142.3 & 17.6 & 504.0 \\
\hline Gut urea-N entry, $\mathrm{g} / \mathrm{d}$ & 96 & 150.1 & 101.5 & 17.4 & 390.0 \\
\hline Urea- $\mathrm{N}$ returned to the ornithine cycle, $\mathrm{g} / \mathrm{d}$ & 80 & 65.0 & 74.7 & 2.8 & 280.0 \\
\hline Urea- $\mathrm{N}$ utilized for anabolism, $\mathrm{g} / \mathrm{d}$ & 76 & 47.0 & 43.8 & 8.8 & 213.8 \\
\hline Urinary urea-N, g/d & 90 & 64.4 & 46.9 & 0.1 & 201.6 \\
\hline Urinary $\mathrm{N}, \mathrm{g} / \mathrm{d}$ & 96 & 113.4 & 76.3 & 13.4 & 291.1 \\
\hline Fecal N, g/d & 96 & 107.8 & 71.8 & 14.7 & 262.0 \\
\hline Fecal $\mathrm{N}$ from urea, $\mathrm{g} / \mathrm{d}$ & 76 & 5.4 & 4.1 & 0.3 & 14.8 \\
\hline Retained N, g/d & 92 & 36.4 & 23.7 & -8.3 & 111.0 \\
\hline
\end{tabular}




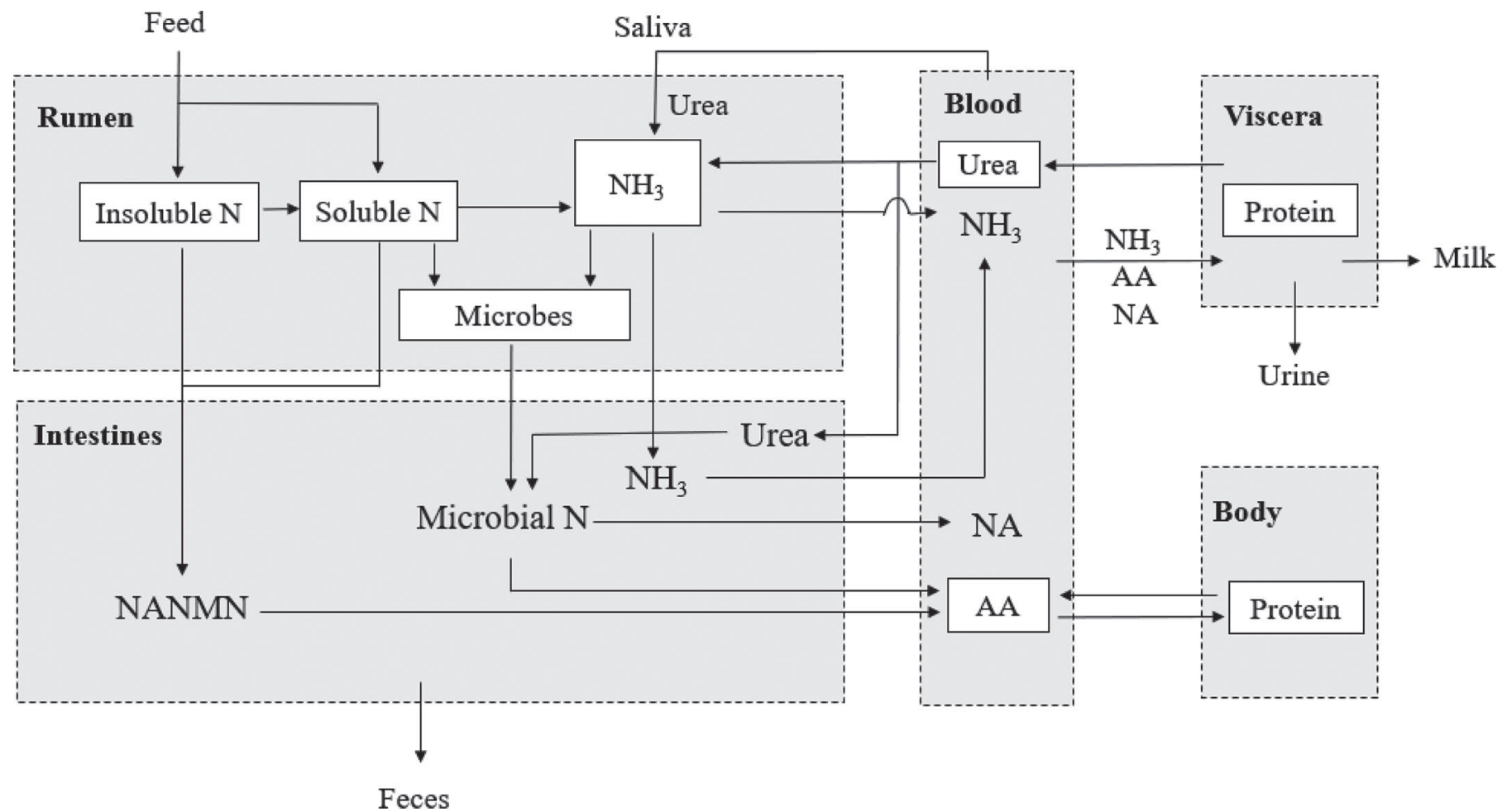

Figure 1. A schematic diagram of nitrogen metabolism in the Molly cow model. NANMN = nonammonia, nonmicrobial nitrogen; NA $=$ nucleic acids. Boxes with dashed lines are compartments; boxes with solid lines represent pools; arrows indicate fluxes.

\section{Model Description}

The mechanistic and dynamic functions of the Molly cow model pertaining to ruminal urea- $\mathrm{N}$ recycling and urinary urea elimination have been described by Baldwin (1995). A schematic of the key elements is presented in Figure 1. As an overview, dietary insoluble protein degradation in the rumen is defined as the balance between rates of degradation and passage. Microbes in the rumen utilize a portion of the soluble protein and AA and ammonia to support microbial growth, and they catabolize an additional portion of the protein and AA, resulting in release of ammonia. Urea entering the rumen is quantitatively converted to ammonia. Mass action functions are used to simulate insoluble protein degradation, microbial metabolism of soluble N, ruminal ammonia absorption, intestinal protein digestion, AA absorption, hepatic urea synthesis, and urinary urea excretion. Microbial growth and urea recycled to the rumen through ruminal epithelium, and utilization for anabolic purposes are represented using MichaelisMenten equations. Conversions among urea, ammonia, and AA are calculated stoichiometrically with adherence to mass balance principles. Concentrations of the key metabolites are predicted at any point in time as state variables in a system of ordinary differential equations, which are numerically integrated over time. State variables include ammonia, soluble protein, AA, insoluble protein, and microbial mass in the rumen, as well as urea and AA in the blood. These mathematical equations were encoded in and solved using ACSL (ver. 3.1.4.2, Aegis Technologies Group Inc., Huntsville, AL).

Model inputs were prepared as previously described (Li et al., 2018) with some modifications. Briefly, dietary nutrient composition (DM, protein, ADF, NDF, lignin, crude fat, starch, and ash) was generated for each treatment by summation of feed values according to the dietary formulas. If the nutrient composition of the constituent ingredients was reported, those values were used; otherwise, tabular values from an integrated feed library were used in place of the missing values. The feed library was generated from the NRC (2001) feed library, a library derived from commercial laboratory data (collected by the National Animal Nutrition Program; www.animalnutrition.org; Tran et al., 2016), and the Cornell Net Carbohydrate and Protein System (CNCPS) feed library. Order of use to construct the integrated library gave preference to the commercial library, followed by the NRC (2001) library, and the CNCPS library. Mean nutrient bias was calculated for each nutrient (OM, protein, $\mathrm{ADF}$, NDF, crude fat, and starch) across diets within each 
study as the difference between calculated dietary nutrient inputs and those reported in the publication when available (Hanigan et al. (2013). The relative bias for the study was used to adjust the nutrient content of each ingredient weighted for the contribution of that ingredient to the dietary nutrient sum for the study. This retained the ingredient level information while reducing dietary mis-specifications and avoiding the introduction of nutrient bias. Rumen protein and starch degradation were calculated following White et al. (2017a,b). Rumen ADF degradation was generated using the same data set and statistical approach as White et al. (2017b):

$$
\begin{gathered}
f_{R d A D F}(\%, \mathrm{DM})=47.5-16.3 \times S t \\
+0.02 \times S t^{2}+0.91 \times D M I
\end{gathered}
$$

where $f_{R d A D F}$ represented rumen ADF degradation (\% of DM); St was dietary starch concentrations (\% of DM); and DMI was expressed as kilograms per day. The concordance correlation coefficient (CCC) for this equation was 0.91 , and the root mean squared error (RMSE) was $11 \%$ of mean.

\section{Model Modifications}

Model modifications were made to the version of Molly described by Gregorini et al. (2015) following conservation of mass principles. For purposes of this description, state variables, generally nutrients, metabolites, or the volume of a pool such as rumen liquid $(\mathrm{kg}$, $\mathrm{L}$, or mol), were denoted as $Q_{A, Y}$, where $A$ denoted the nutrient or metabolite in compartment $Y ; C_{A, Y}$ represented the concentration of $A$ in compartment $Y(\mathrm{~kg} / \mathrm{L}$ or mol/L; primarily in ruminal fluid or blood); the flux of nutrients within the system was denoted as $\boldsymbol{F}_{\boldsymbol{A B}, Y Z}$ $(\mathrm{kg} / \mathrm{d}$ or $\mathrm{mol} / \mathrm{d})$, where $\boldsymbol{A}$ denoted a substrate, $\boldsymbol{B}$ a product, $\boldsymbol{Y}$ the location of the conversion, and in the case of transfer from one compartment to another with or without interconversion, $Z$ represented the receiving compartment; $f_{A B, Y Z}$ represented a stoichiometric constant for conversion of substrate $A$ to product $B$; $\boldsymbol{K}_{A B, Y Z}$ represented a rate constant (variable units) for conversion of $A$ to $B$, and $\boldsymbol{X}_{A B, Y Z}$, denoted a sensitivity exponent for conversion of $A$ to $B$ (variable units); $\boldsymbol{J}_{\boldsymbol{A}}$ represented an inhibition constant for inhibitor A. Specification of a single entity $(A)$ or pool location $(Y)$ was used when no conversion or location change occurred.

Initial model evaluations indicated that residuals for ruminal microbial $\mathrm{N}$ outflow were positively correlated with ruminal ammonia concentrations, suggesting that microbial $\mathrm{N}$ flow from the rumen was underpredicted as ruminal ammonia concentrations increased. Therefore, an exponential factor $\left(X_{E A m}\right)$ was added to the microbial growth equation to allow adjustment of sensitivity to ruminal ammonia concentrations if required $\left(F_{M i G, R u m}\right.$, $\mathrm{kg} / \mathrm{d})$.

$$
\begin{aligned}
F_{\text {MiG }, \text { Rum }} & =\left(F_{A T P F, \text { Rum }}-F_{A T P M, \text { Rum }}\right) \\
& \times\left(0.012+\frac{K_{Y A T P, R u m}}{1+K_{A a M i, R u m} / C_{A a, \text { Rum }}}\right) \\
& \times\left(\frac{1}{1+\left(K_{A m M i, R u m} / C_{A m, \text { Rum }}\right)^{X_{E A m}}}\right) \\
& \times\left(1+\frac{C_{\text {Lipid }, F d}}{C_{\text {Fat }, F d} \times K_{F a t, F d}}\right),
\end{aligned}
$$

where $F_{A T P F, R u m}$ represented ATP production generated from nutrient fermentation in the rumen $(\mathrm{mol} / \mathrm{d})$; $F_{A T P M, R u m}$ represented ATP used for microbial maintenance $(\mathrm{mol} / \mathrm{d}) ; K_{Y A T P, R u m}$ was an efficiency variable defining the yield of microbial DM per mole of ATP $(\mathrm{kg} / \mathrm{mol}) ; K_{A a M i, R u m}$ and $K_{A m M i, R u m}$ were rate constants for the effect of ruminal concentrations of AA and ammonia on microbial growth $(\mathrm{L} / \mathrm{mol})$; and $C_{A a, \text { Rum }}$ and $C_{A m, \text { Rum }}$ represented ruminal concentrations of $\mathrm{AA}$ and ammonia $(\mathrm{mol} / \mathrm{L}) ; C_{\text {Lipid,Fd }}$ was the dietary concentration of endogenous lipid (\%, intrinsic plant lipids excluding storage oils and fats); $C_{F a t, F d}$ represented the dietary concentration of added fat (\%); and $K_{F a t, F d}$ was the rate constant for the effect of added fat on microbial growth $(\% / \%)$.

Ammonia passage to the small intestine ( $F_{\text {Am, RumInt }}$, $\mathrm{mol} / \mathrm{d}$ ) was simulated as a mass action function of the ruminal ammonia pool size $\left(Q_{A m, R u m}, \mathrm{~mol}\right)$ and rumen liquid outflow rate $\left(K_{\text {Liq,RumInt }}, \mathrm{d}^{-1}\right)$ :

$$
F_{\text {Am,RumInt }}=Q_{A m, \text { Rum }} \times K_{\text {Liq, RumInt }} .
$$

The differential equations describing the change in $Q_{A m, \text { Rum }}$ with respect to time, ruminal total $\mathrm{N}$ outflow $(\mathrm{kg} / \mathrm{d})$, and ruminal NANMN outflow $(\mathrm{kg} / \mathrm{d})$ were altered to include consideration of $F_{\text {Am,RumInt }}$.

Ammonia flow from the rumen was assumed completely absorbed and converted to urea in the liver, as was previously assumed for ammonia absorbed from the rumen:

$$
F_{A m U r, \text { Vis }}=\left(F_{A m, \text { RumBld }}+F_{A m, \text { RumInt }}\right) \times f_{A m U r},
$$


where $F_{\text {AmUr,Vis }}$ was ammonia conversion to urea $(\mathrm{mol} / \mathrm{d}) ; \quad F_{\text {Am,RumBld }}$ represented ruminal ammonia absorption $(\mathrm{mol} / \mathrm{d})$; and $f_{A m U r}$ was the stoichiometric coefficient for conversion of ammonia to urea $(0.5 \mathrm{~mol}$ of $\mathrm{NH}_{3} / \mathrm{mol}$ of urea).

Urea recycling to the rumen is represented as the sum of transfer across the ruminal epithelium $\left(F_{U r, B l d R u m(T r a n s)}\right.$, $\mathrm{mol} / \mathrm{d})$ and salivary delivery $\left(F_{U r, B l d R u m(S a l}\right), \mathrm{mol} / \mathrm{d}$; Baldwin, 1995). Those 2 fluxes were summed to provide an overall ruminal urea entry rate $\left(F_{U r, B l d R u m}, \mathrm{~mol} / \mathrm{d}\right)$, which could be compared with the measured urea entry rates:

$$
F_{U r, \text { BldRum }}=F_{U r, \text { BldRum }(\text { Trans })}+F_{U r, B l d R u m(\text { Sal })} .
$$

Lapierre and Lobley (2001) demonstrated that gut urea entry was composed of ruminal and intestinal urea- $\mathrm{N}$ entry. To estimate intestinal urea entry rate from a single measured gut entry rate $\left(F_{U r, B l d G u t}, \mathrm{~mol} / \mathrm{d}\right)$ requires an assumption of the fractional transfer into the rumen and the intestine. The true split is driven by tissue mass, the transport activity per unit of mass, and blood flow. The latter is proportional to tissue activity and fermentation rate in the lumen (Storm et al., 2011, 2012), and thus it was assumed that ruminal urea entry across rumen epithelium and postruminal urea entry was proportional to DM disappearance in each compartment $\left(f_{\text {DMDis,Rum }}, \mathrm{kg} / \mathrm{kg}\right)$ :

$$
\begin{gathered}
F_{D M D i s, \text { Rum }}=F_{D M, F d R u m}-F_{D M, \text { RumInt }}, \\
F_{D M D i s, \text { Int }}=F_{D M, \text { RumInt }}-F_{D M, \text { IntFec }}, \\
f_{\text {DMDis,Rum }}=\frac{F_{D M D i s, \text { Rum }}}{F_{D M D i s, \text { Int }}}, \\
F_{U r, \text { BldInt }}=\frac{F_{U r, \text { BldRum }(\text { Trans })}}{f_{D M D i s, \text { Rum }}}, \\
F_{U r, \text { BldGut }}=F_{U r, \text { BldRum }}+F_{U r, B l d I n t},
\end{gathered}
$$

where ruminal DM disappearance $\left(F_{\text {DMDis,Rum }}, \mathrm{kg} / \mathrm{d}\right)$ was calculated by subtracting ruminal DM outflow $\left(F_{D M, \text { RumInt }}, \mathrm{kg} / \mathrm{d}\right)$ from DMI $\left(F_{D M, F d R u m}, \mathrm{~kg} / \mathrm{d}\right)$; postruminal disappearance DM $\left(F_{D M D i s, I n t}, \mathrm{~kg} / \mathrm{d}\right)$ was equal to ruminal DM outflow minus fecal DM outflow $\left(F_{D M, \text { IntFec }}\right.$, $\mathrm{kg} / \mathrm{d}$ ); and $F_{\text {Ur.BldInt }}$ was the intestinal urea entry rate $(\mathrm{mol} / \mathrm{d})$. This likely overestimates postruminal entry because a fraction of the DM disappearance is not from fermentative action. However, given that urea freely equilibrates across cell membranes, the presence of DM in the small intestine will draw urea in, even though it may not be converted to ammonia until it passes to the large intestine. Thus, assuming that no urea enters the small intestine would have also resulted in bias. Additional data are required to address this assumption.

Urea recycled to the lower gut was assumed to be converted to ammonia, and then captured by microbes as microbial $\mathrm{N}$ in the hind gut $\left(F_{U r M i . I n t}, \mathrm{~mol} / \mathrm{d}\right)$, excreted in feces $\left(F_{U r A m, I n t F e c}, \mathrm{~mol} / \mathrm{d}\right)$, or reabsorbed $\left(F_{\text {UrAm,Int }}\right.$, $\mathrm{mol} / \mathrm{d}$ ). Lapierre and Lobley (2001) indicated that the contribution of urea- $\mathrm{N}$ to support microbial protein synthesis was minor in the lower gut compared with that in the rumen. It seems likely that capture by microbes would be proportional to fermentation rate, and given that DM disappearance was used to define entry, we further assumed that $25 \%$ of the amount entering the intestine was captured in microbial $\mathrm{N}$, thus approximating proportionality with fermentative activity:

$$
\begin{gathered}
F_{U r M i, I n t}=0.25 \times F_{U r, \text { BldInt }}, \\
F_{U r A m, \text { IntFec }}=K_{U r, \text { IntFec }}+K_{S l p U r, \text { IntFec }} \times F_{U r, B l d I n t}, \\
F_{U r A m, I n t}=\frac{F_{U r, \text { BldInt }}-F_{U r M i, I n t}-F_{U r A m, I n t F e c}}{f_{A m U r}}
\end{gathered}
$$

where $K_{S l p U r, I n t F e c}$ and $K_{U r, I n t F e c}$ were parameters used to estimate fecal ammonia- $\mathrm{N}$ excretion.

The representation of urea synthesis $\left(F_{\text {AmUr,Liv }}\right.$, $\mathrm{mol} / \mathrm{d}$ ) was modified to include the contribution from ammonia absorbed from the hind gut:

$$
F_{A m U r, L i v}=F_{A a U r, V i s}+F_{A a U r, G e s t}+F_{A m U r, V i s}+F_{U r A m, I n t} \times f_{A m U r},
$$

where $F_{\text {AaUr, Vis }}$ represented deamination of $\mathrm{AA}$ in the viscera. Viscera is assumed to be the primary site of AA degradation, with the remainder occurring in the gravid uterus $\left(F_{A a U r, G e s t}, \mathrm{~mol} / \mathrm{d}\right)$, as described by Hanigan et al. (2009).

Urinary urea excretion $\left(F_{\text {Ur, BldUrin }}, \mathrm{mol} / \mathrm{d}\right)$ was originally described as a mass action function of blood urea concentrations (Baldwin, 1995). However, as Li et al. (2018) pointed out, blood urea concentrations do not scale with body mass, and thus flux was biased with respect to body size. This is a deviation relative to 
all other equations of this type in the model, which are driven by pool size rather than concentration. Conceptually, renal urea clearance is a function of blood flow, the concentration of urea in renal blood, and the activity of the kidney (Stevens and Levey, 2005). However, blood flow is not represented in the model. It was assumed that blood flow was proportional to tissue mass and activity with the tissues grouped as high (viscera) and low (body) activities (Baldwin, 1995). It was also assumed that blood volume was proportional to BW, which is a well-documented relationship. Given these relationships, blood volume, blood flow, and tissue activity are all proportional to BW, and blood flow $\times$ blood concentration is also proportional to blood volume $\times$ concentration, which is the definition of the pool size. Thus, the pool size represents renal urea supply, and because renal capacity also scales with BW, we can represent glomerular filtration as a function of the pool size, but not as a function solely of concentration. Thus, the prior representation was a mistake, which was corrected by altering the equation to be driven by the blood urea pool size $\left(Q_{U r, B l d}, \mathrm{~mol}\right)$, which scales appropriately with BW:

$$
F_{U r, \text { BldUrin }}=Q_{U r, B l d} \times K_{U r, B l d U r i n},
$$

where $K_{U r, B l d U r i n}$ represents the mass action constant for urea excretion by the kidney.

Digested microbial NPN was assumed to be composed entirely of purines and pyrimidines and entirely excreted in the urine after derivatization in the liver. This is a deviation from the earlier model, which did not represent absorption of nucleic acids from microbes. Thus, urinary $\mathrm{N}\left(F_{N, \text { Urin }}, \mathrm{kg} / \mathrm{d}\right)$ consisted of urinary urea-N $\left(F_{\text {UrN,BldUrin }}, \mathrm{kg} / \mathrm{d}\right)$ plus purine derivative-N $\left(F_{\text {Nn,MiUrin }}, \mathrm{kg} / \mathrm{d}\right)$ :

$$
\begin{gathered}
F_{N n, \text { MiUrin }}=F_{\text {Mi,RumInt }} \times f_{M i N n N n} \times K_{P i, \text { MiFec }} \times 0.16, \\
F_{U r N, \text { BldUrin }}=\frac{F_{U r, B l d U r i n}}{f_{A m U r}} \times K_{M w t N}, \\
F_{N, \text { Urin }}=F_{U r N, B l d U r i n}+F_{N n, \text { MiUrin }},
\end{gathered}
$$

where $F_{\text {Mi,RumInt }}$ was the ruminal microbial protein outflow $(\mathrm{kg} / \mathrm{d}) ; f_{M i N n N n}$ represented the fraction of total microbial $\mathrm{N}$ that was NPN; $K_{P i, M i F e c}$ represented the intestinal digestion coefficient for microbial protein, which was 0.75 (Baldwin, 1995); and $K_{M w t N}$ was the N molecular mass of $0.014 \mathrm{~kg} / \mathrm{mol}$.
Fecal $\mathrm{N}$ excretion $\left(F_{N, I n t F e c}, \mathrm{~kg} / \mathrm{d}\right)$ was updated to reflect absorption of nonprotein microbial $\mathrm{N}$ and urea recycled into the hind gut:

$$
\begin{aligned}
& F_{N, \text { IntFec }}= \\
& \left(\begin{array}{l}
F_{P i, \text { MiFec }}+F_{\text {Nn,MiFec }}+F_{P i, \text { IntFec }} \\
+\left(F_{U r M i, I n t} / f_{A m U r}\right)+\left(F_{U r A m, \text { IntFec }} / f_{A m U r}\right)
\end{array}\right) \times K_{M w t N},
\end{aligned}
$$

where $F_{P i, \text { MiFec }}$ was undigested microbial protein $\mathrm{N}$ $(\mathrm{mol} / \mathrm{d}) ; F_{N n, M i F e c}$ was undigested nonprotein microbial $\mathrm{N}(\mathrm{mol} / \mathrm{d}) ; F_{P i, \text { IntFec }}$ represented undigested insoluble feed protein $\mathrm{N}(\mathrm{mol} / \mathrm{d}) ; F_{U r M i, I n t}$ referred to microbial $\mathrm{N}$ captured from recycled urea-N in the hindgut $(\mathrm{mol} / \mathrm{d})$; $F_{\text {UrAm,IntFec }}$ was ammonia-N excreted in feces $(\mathrm{mol} / \mathrm{d})$ that was derived from blood urea; $f_{A m U r}$ was a stoichiometric parameter $(0.5 \mathrm{~mol} / \mathrm{mol})$ for conversion of ammonia to urea.

\section{Infusion Variables}

Several studies were conducted that used infusions of casein, glucose or VFA (Wickersham et al., 2008, 2009b; Bailey et al., 2012a,b; Titgemeyer et al., 2012; Batista et al., 2016). To represent their effects, consideration of infused nutrients was added to the model as follows. Ruminally infused VFA were added as additional fluxes to each of the VFA differential equations $\left(\mathrm{d} Q_{A c, \text { Rum }} / \mathrm{d} t\right.$, $\left.\mathrm{d} Q_{P r, R u m} / \mathrm{d} t, \mathrm{~d} Q_{B u, R u m} / \mathrm{d} t, \mathrm{~mol} / \mathrm{d}\right):$

$$
\begin{aligned}
\frac{\mathrm{d} Q_{A c, \text { Rum }}}{\mathrm{d} t}= & F_{A c, \text { FdRum }}+F_{C s A c, \text { Rum }}+F_{A a A c, \text { Rum }}+F_{L a A c, \text { Rum }} \\
& +F_{\text {InfAc,Rum }}-F_{A c, \text { RumBld }}-F_{A c, \text { RumInt }}
\end{aligned}
$$

$$
\begin{aligned}
\frac{\mathrm{d} Q_{P r, R u m}}{\mathrm{~d} t}= & F_{C s P r, R u m}+F_{A a P r, R u m}+F_{L a P r, R u m} \\
& +F_{I n f P r, R u m}-F_{P r, R u m B l d}-F_{P r, R u m I n t}, \\
\frac{\mathrm{d} Q_{B u, \text { Rum }}}{\mathrm{d} t}= & F_{B u, F d R u m}+F_{C s B u, \text { Rum }}+F_{A a B u, \text { Rum }} \\
& +F_{\text {InfBu,Rum }}-F_{B u, \text { RumBld }}-F_{B u, \text { RumInt }},
\end{aligned}
$$

where $F_{A c, F d R u m}$ and $F_{B u, F d R u m}$ represented fluxes of dietary acetate and butyrate from silage $(\mathrm{mol} / \mathrm{d})$; $F_{C s A c, R u m}, F_{C s P r, R u m}$, and $F_{C s B u, R u m}$ referred to acetate, propionate, and butyrate derived from carbohydrate fermentation in the rumen $(\mathrm{mol} / \mathrm{d}) ; F_{A a A c, R u m}, F_{A a P r, R u m}$, and $F_{A a B u, R u m}$ were conversions of AA to each of the VFA 
$(\mathrm{mol} / \mathrm{d}) ; F_{\text {LaAc,Rum }}$ and $F_{\text {LaPr,Rum }}$ represented conversions of lactate to acetate and propionate $(\mathrm{mol} / \mathrm{d}) ; F_{\text {InfAc,Rum }}$, $F_{\text {InfPr,Rum }}$, and $F_{\text {InfBu,Rum }}$ represented ruminal VFA infusion rates $(\mathrm{mol} / \mathrm{d})$ of each; $F_{A c, \text { RumBld}}, F_{P r, \text { RumBld}}$, and $F_{B u, \text { RumBld }}$ represented absorptions of each of the VFA $(\mathrm{mol} / \mathrm{d})$; and $F_{A c, \text { RumInt }}, F_{\text {Pr,RumInt }}$, and $F_{B u, \text { RumInt }}$ referred to VFA passage from the rumen $(\mathrm{mol} / \mathrm{d})$.

Ruminally infused glucose was added as a flux to the soluble carbohydrate differential equation $(\mathrm{mol} / \mathrm{d})$ :

$$
\begin{aligned}
\frac{\mathrm{d} Q_{C s, \text { Rum }}}{\mathrm{d}_{t}}= & F_{S c T C s, \text { Rum }}+F_{S t C s, \text { Rum }}+F_{\text {HaCs }, \text { Rum }} \\
& +F_{H c C s, \text { Rum }}+F_{C e C s, \text { Rum }}+F_{\text {InfGl,Rum }} \\
& -F_{C s F v, \text { Rum }}-F_{C s M i, \text { Rum }}-F_{C s, \text { RumInt }}
\end{aligned}
$$

where $F_{S c T C s, \text { Rum }}$ and $F_{S t C s, \text { Rum }}$ represented dietary intake of total soluble carbohydrate expressed in 6-carbon equivalents and soluble starch $(\mathrm{mol} / \mathrm{d}) ; F_{H a C s, \text { Rum }}$, $F_{H c C s, \text { Rum }}$, and $F_{C e C s, \text { Rum }}$ referred to ruminal degradations of starch, hemicellulose, and cellulose to soluble carbohydrate $(\mathrm{mol} / \mathrm{d}) ; F_{\text {InfGl,Rum }}$ was ruminal glucose infusion $(\mathrm{mol} / \mathrm{d}) ; F_{C s F v, \text { Rum }}, F_{C s M i, \text { Rum }}$, and $F_{C s, \text { RumInt }}$ represented soluble carbohydrate degradation, utilization for microbial growth, and passage from the rumen $(\mathrm{mol} / \mathrm{d})$.

Abomasally infused glucose was assumed to be completely absorbed and thus added to the absorbed glucose flux $\left(F_{G l, \text { IntBld }}, \mathrm{mol} / \mathrm{d}\right)$ :

$$
\begin{aligned}
F_{G l, \text { IntBld }}= & F_{\text {HaGl,Int }}+F_{C s, \text { RumInt }}+F_{M i G l, \text { Int }} \\
& +F_{\text {MiLGl,Int }}+F_{\text {InfGl,Int }},
\end{aligned}
$$

where $F_{\text {HaGl,Int }}$ was dietary starch digestion $(\mathrm{mol} / \mathrm{d})$; $F_{\text {MiGl.Int }}$ represented microbial starch digestion in the lower gut $(\mathrm{mole} / \mathrm{d}) ; F_{\text {MiLGl,Int }}$ referred to a flux that equals 2 units of glycerol from digested microbial lipid $(\mathrm{mol} / \mathrm{d})$; and $F_{\text {InfGl,Int }}$ was postruminal glucose infusion.

Ruminally infused casein was incorporated as a component of the diet with the assumption that it was $100 \%$ soluble. Postruminally infused casein was also considered as a dietary ingredient with zero solubility and a zero rate of ruminal degradation so that all of it passed from the rumen.

Model changes were verified for mathematical consistency using a reference observation from the data set. Predictions of ruminal ammonia, microbial mass, and blood urea pool size $(\mathrm{mol})$, with respect to simulation time, were assessed before and after model modifications to determine if the changes inappropriately altered overall model balance. The reference inputs were a 598-kg lactating Holstein dairy cow consuming 26.3 $\mathrm{kg}$ of $\mathrm{DM} / \mathrm{d}$ of a diet containing $\mathrm{CP}$, fat, starch, NDF, and ADF of $16.6,5.5,33.7,29.8$, and $18.9 \%$ of DM.

\section{Simulation Settings, Parameter Estimation, and Model Evaluations}

The model was solved using a fourth-order, variablestep Runge-Kutta integration algorithm with a maximum step size of $0.005 \mathrm{~d}$. Model stability and time to steady state were assessed by simulating for $14 \mathrm{~d}$ using the reference inputs, followed by alteration of the rate constant for ruminal ammonia absorption $\left(K_{A m, \text { RumBld }}\right)$ from $10.44 \mathrm{~d}^{-1}$ to 20 on $\mathrm{d} 14$, continuation of the run for another $14 \mathrm{~d}$, and then returning the rate constant to 10.44 , and continuation of the simulation for an additional $14 \mathrm{~d}$ (Figure 2A). This process was repeated after model modification and parameter estimation using a starting and ending value of $5.76 \mathrm{~d}^{-1}$ for $K_{A m, \text { RumBld }}$ (Figure 2B). Pool sizes of ruminal ammonia, microbial mass, and blood urea were recorded by day and plotted with respect to time to verify model stability and code accuracy, and to assess model behavior and time to steady state.

Model parameters were estimated simultaneously by fitting to the observed data using the Direction Set optimization algorithm (Press, 2007) provided in ACSL to maximize the log-likelihood function. Predicted values were sampled at steady state on d 14 (Figure 2) for comparison with observed values.

Model accuracy and precision were assessed based on the log-likelihood function, RMSE; the proportions of mean squared error (MSE) associated with mean bias, slope bias, and dispersion (Bibby and Toutenburg, 1977); and CCC (Lin, 1989). Residual errors were also visually appraised to identify any additional patterns that may have been resident in the data.

Following model modifications and parameter estimation, simulations were conducted to assess $\mathrm{N}$ efficiency using 2 different feeding scenarios. The simulated animal was initialized as a Holstein cow weighing $600 \mathrm{~kg}$ at d 70 of lactation and consuming $20 \mathrm{~kg}$ of DM per day. For feeding strategy 1, there were 11 dietary CP concentrations ranging from 10 to $20 \%$ of DM. The diets all contained fat, starch, soluble starch, NDF, $\mathrm{ADF}$, and ash concentrations of $6,30,9,30,20$, and $6 \%$ of DM, respectively; thus, CP was substituted for residual OM, which is primarily pectins and organic acids. Dietary RUP concentration was set to $6 \%$ of DM for all diets, with variation in RDP being the sole contributor to varying dietary CP. This resulted in dietary RDP concentrations from 4 to $14 \%$ of DM. For feeding strategy 2, dietary $\mathrm{CP}$ was held constant at $16 \%$ of DM and 9 different concentrations of RUP ranging from 10 to $90 \%$ of $\mathrm{CP}$ were used. In this case, RUP was substituted for RDP given a constant CP content. The remaining nutrient concentrations were the same as for feeding strategy 1. Model predictions of total ru- 
A - $\mathrm{Q}_{\mathrm{Am}, \mathrm{Run}} \Delta \mathrm{Q}_{\mathrm{Ur}, \mathrm{BM}} \boldsymbol{\sim} \mathrm{Q}_{\mathrm{Mi}, \mathrm{Rum}}$

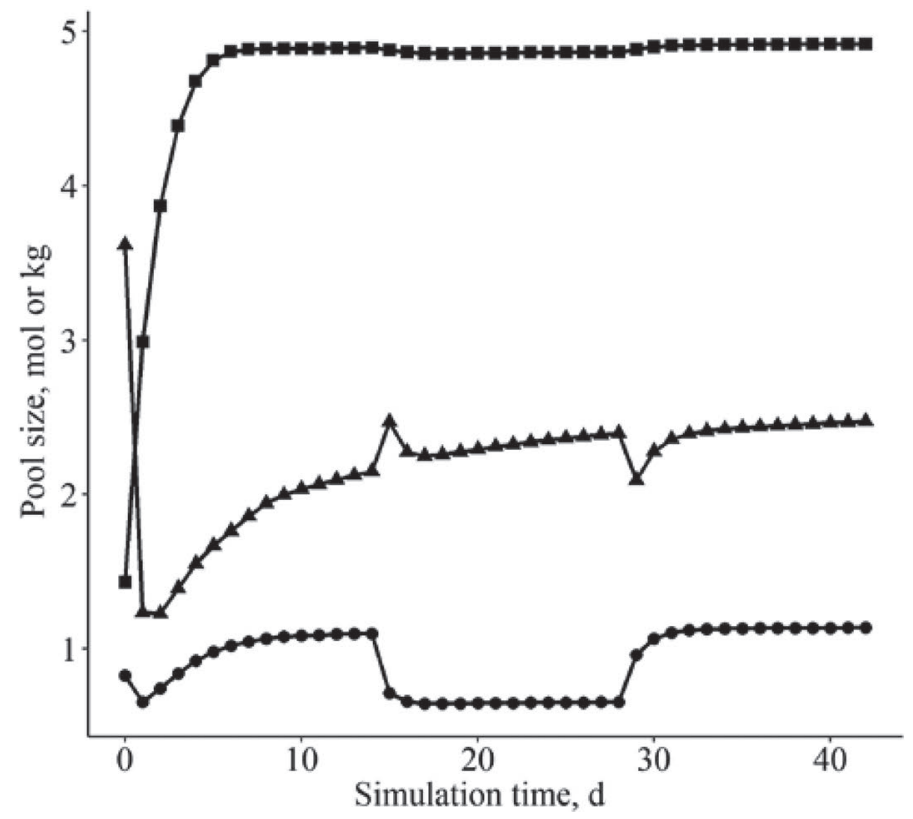

B

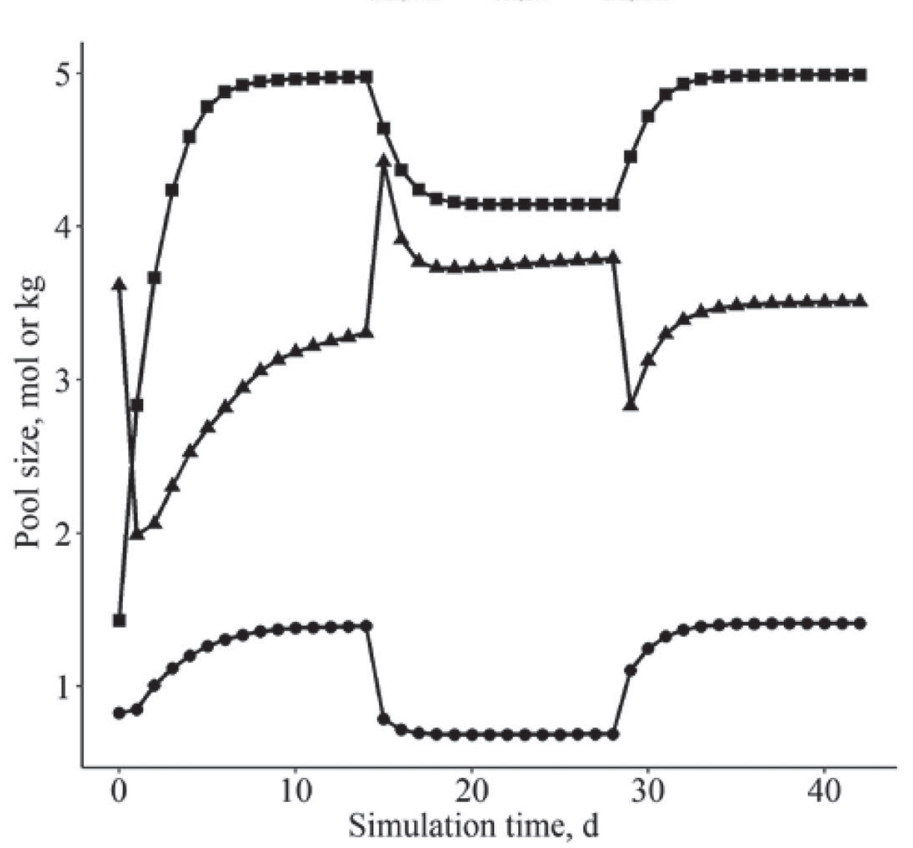

Figure 2. Ruminal ammonia $\left(Q_{A m, R u m}, \mathrm{~mol}\right)$, microbial mass $\left(Q_{M i, R u m}, \mathrm{~kg}\right)$, and blood urea $\left(Q_{U r, B l d}\right.$, mol $)$ pools with respect to simulation time for the initial model (A) and the modified model (B). The rate constant for ruminal ammonia absorption $\left(K_{A m, R u m B l d}\right.$, $\left.\mathrm{d}^{-1}\right)$ was set to 10.44 at the start of the simulation for the initial model, changed to 20 on d 14, and returned to 10.44 on d 28 . $K_{\text {Am, RumBld }}$ was set to 5.01 at the start of the simulation for the modified model, set to 20 on d 14, and returned to 5.01 on d 28 .

minal $\mathrm{N}$ outflow $\left(F_{N, \text { RumInt }}, \mathrm{kg} / \mathrm{d}\right)$, microbial $\mathrm{N}$ outflow $\left(F_{\text {MiN,RumInt }}, \mathrm{kg} / \mathrm{d}\right)$, NANMN outflow $\left(F_{\text {NANMN,RumInt }}\right.$, $\mathrm{kg} / \mathrm{d}$ ), ammonia-N converted to ruminal microbial $\mathrm{N}$ $\left(F_{A m M i, R u m}, \mathrm{~kg} / \mathrm{d}\right)$, ammonia generated in the rumen from recycled urea $\left(F_{U r A m, R u m}, \mathrm{~mol} / \mathrm{d}\right)$, total ammonia production $\left(F_{A m, \text { Rum }}, \mathrm{mol} / \mathrm{d}\right)$, blood urea entry rate $\left(F_{A m U r, L i v}, \mathrm{~mol} / \mathrm{d}\right)$, gut urea entry rate $\left(F_{U r, B l d G u t}, \mathrm{~mol} / \mathrm{d}\right)$, and urinary urea excretion $\left(F_{U r, B l d U r i n}, \mathrm{~mol} / \mathrm{d}\right)$ were collected. The proportion of microbial $\mathrm{N}$ synthesized from ammonia-N was calculated as $F_{A m M i, R u m}$ divided by $F_{\text {MiN,RumInt }}$. The proportion of total ammonia generated from recycled urea was calculated as $F_{U r A m, \text { Rum }}$ divided by $F_{A m, \text { Rum }}$.

\section{Regression Analyses}

Regressions were conducted using a mixed linear model with study as a random effect using the lmer function of the lme4 package (version 1.1-17; Bates et al., 2015) in R (version 3.3.0; R Development Core Team, 2015) to quantify relationships between observed dietary $\mathrm{N}$ intake and observed ruminal $\mathrm{N}$ outflow, observed blood urea entry, and relationships between observed blood urea entry and observed gut urea entry or urinary urea excretion. Coefficients of determination were defined as follows: $\mathbf{R}^{2}{ }_{m}$ is the marginal $R^{2}$, which represents the proportion of variance that can be ex- plained by the fixed effect, and $\mathbf{R}_{\mathrm{c}}{ }_{\mathrm{c}}$ is the conditional $\mathrm{R}^{2}$, which indicates the proportion of variance that can be explained by the fixed effect plus the random effect.

\section{RESULTS AND DISCUSSION}

\section{Steady State and Model Verifications}

Ruminal ammonia (mol), ruminal microbial mass $(\mathrm{kg})$, and blood urea (mol) pool sizes with respect to simulation time before and after perturbations of the ruminal ammonia absorption constant are shown in Figure 2. After $10 \mathrm{~d}$ of model simulation, changes in pool sizes of these 3 variables were negligible, suggesting that all the variables associated with these $\mathrm{N}$ pools had reached steady state. When challenging the model by changing the rate constant for ruminal ammonia absorption $\left(K_{A m, \text { RumBld }}, \mathrm{d}^{-1}\right)$ on d 14 and 28 , the model returned to apparent steady state in $7 \mathrm{~d}$, supporting selection of a simulation time of $14 \mathrm{~d}$ to represent steadystate values. The model was found to be stable and returned to initial pool sizes after perturbation when the parameter values were returned to the initial values on d 28 , suggesting the code was acting as expected.

Increasing $K_{A m, \text { RumBld }}$ on d 14 greatly decreased ruminal ammonia pool size in the modified model (Figure 2 ). As a consequence, microbial pool size was decreased 
and blood urea pool size was increased (Figure 2B), which contrasts with the very small changes in microbial and blood urea pool sizes for the initial model (Figure $2 \mathrm{~A}$ ). Thus, the altered model and associated parameters resulted in greater microbial growth sensitivity to ruminal ammonia concentrations, which was consistent with our previous observations of model behavior $(\mathrm{Li}$ et al., 2018).

\section{Ruminal Ammonia Metabolism}

Ruminal ammonia, as a major end-product of ruminal fermentation, is a vital indicator of ruminal $\mathrm{N}$ metabolism. Ammonia is produced from microbial degradation of dietary AA, dietary NPN, and salivary and blood urea-N entering the rumen, and it is utilized by microbes to synthesize protein, absorbed from the rumen, or passed from the rumen in the liquid fraction (Figure 1). After model improvements and refitting, the RMSE for ruminal ammonia concentrations decreased from 53.1 to $43.7 \%$, with a decrease in mean bias from 16.4 to $7.7 \%$ and a decrease in slope bias from 13.2 to $8.4 \%$. These results support our hypothesis regarding the representation of these transactions; however, precision was still relatively poor, suggesting that the observed ammonia concentrations were highly variable. Nolan (1975) demonstrated that the ammonia pool can completely turn over in less than $2 \mathrm{~h}$. Thus, time of sampling relative to a meal and the size of the meal are important determinants of ruminal ammonia concentrations that are rarely reported. In most cases, the animals were fed frequently to minimize this problem, but even with 2-h feeding intervals, ammonia concentrations at sampling could vary if the diet is highly degradable. Sampling location is another source of variation. Wohlt et al. (1976) reported that concentrations of ruminal ammonia were greatest in the dorsal region of the rumen and were lower in samples obtained by stomach tube compared with samples taken via rumen cannula. Thus, variation in observed values also likely exists due to sampling location. Neither of these potential sources of variation can be reproduced in the model as currently formulated, thus contributing to the lack of precision.

Substantial amounts of ammonia are generated from microbial degradation of dietary protein in the rumen. On average, ruminal NANMN outflow accounted for $30 \%$ of incremental dietary $\mathrm{N}$ intake (Figure 3C), and thus $70 \%$ of dietary protein was degraded in the rumen. Intercept and slope scalars $\left(K_{R U P, R u m}\right.$ and $\left.K_{S l p R U P, R u m}\right)$ were introduced by Hanigan et al. (2013) to scale in situ measures of ingredient $\mathrm{CP}$ degradation rates so the model predictions more closely aligned with observed extent of degradation. In theory, if the in situ measures and the model were perfect representations of reality, the intercept would be 0 and the slope would be 1 . Given the needed adjustments of in situ assessments, we must conclude that either protein degradation rates determined in situ are biased or the model structure is biased. In the revised model, $K_{R U P, R u m}$ and $K_{\text {SlpRUP,Rum }}$ moved toward 0 and 1 , respectively, compared with earlier estimates, implying that model structure was at least part of the problem, although ingredient protein degradation rates were also updated (White et al., 2017a). The revised estimates of the in situ adjustment parameters slightly decreased RMSE for ruminal NANMN from 28.8 to $26.2 \%$, with mean bias decreased from 12.8 to 10.6 and slope bias decreased from 8.7 to $7.9 \%$ (Table 2; Figure 4).

A portion of ammonia comes from microbial hydrolysis of recycled urea either directly transferred from blood across ruminal epithelium or via saliva. In the model, urea flowing into the rumen via saliva is calculated from blood urea concentrations multiplied by saliva volume, and urea passing across rumen epithelium is simulated using a Michaelis-Menten equation driven by blood urea concentrations and inhibited by ruminal ammonia concentrations (Baldwin, 1995). Refitting the maximal rate of blood urea conversion to ruminal ammonia $\left(V m_{U r A m, R u m}\right)$ and the inhibition constant for the effect of ammonia on blood urea conversion to ruminal ammonia $\left(J_{A m}\right)$ resulted in an increase in the maximal rate $\left(V m_{U r A m, R u m}\right)$ from 56.7 to $84 \pm 3.4 \mathrm{mmol} / \mathrm{d}$ (Table 3 ), and an increase in the ruminal ammonia inhibition constant $\left(J_{A m}\right)$ from 0.003 to $0.0074 \pm 1.1 \times 10^{-5} \mathrm{~L} /$ mol. The revised parameters resulted in decreased RMSE for predictions of gut urea-N entry from 70.5 to $26.7 \%$, primarily due to substantially decreased mean bias from 57.5 to $0.8 \%$. A larger $V m_{U r A m, R u m}$ indicates greater maximal rates of transfer of blood urea into the rumen. At ruminal ammonia concentrations of 5 , 10 , and $15 \mathrm{mM}, 76,62$, and $52 \%$ of the maximal urea transfer rate would be achieved with $J_{A m}$ at 0.0074 , supporting the inhibitory effect of ruminal ammonia on urea transfer.

Ammonia is an essential substrate for microbial protein synthesis. Microbial N outflow represents approximately $57 \%$ of the incremental total dietary $\mathrm{N}$ intake (Figure 3B). Model simulation results indicated that 65 to $76 \%$ of microbial $\mathrm{N}$ was derived from ammonia depending on the diet, which was consistent with estimates of the contribution of total ammonia- $\mathrm{N}$ to bacterial N ranging from 64 to $80 \%$ (Pilgrim et al., 1970; Nolan and Leng, 1972). Fitting the maximal rate of growth of microbes from AA $\left(K_{Y A T P, R u m}\right)$ resulted in a value of $0.064 \pm 0.002 \mathrm{~kg} / \mathrm{mol}$ compared with the prior value of 0.03 . The affinity constant for microbial growth stimulation by ammonia $\left(K_{A m M i, R u m}\right)$ was 

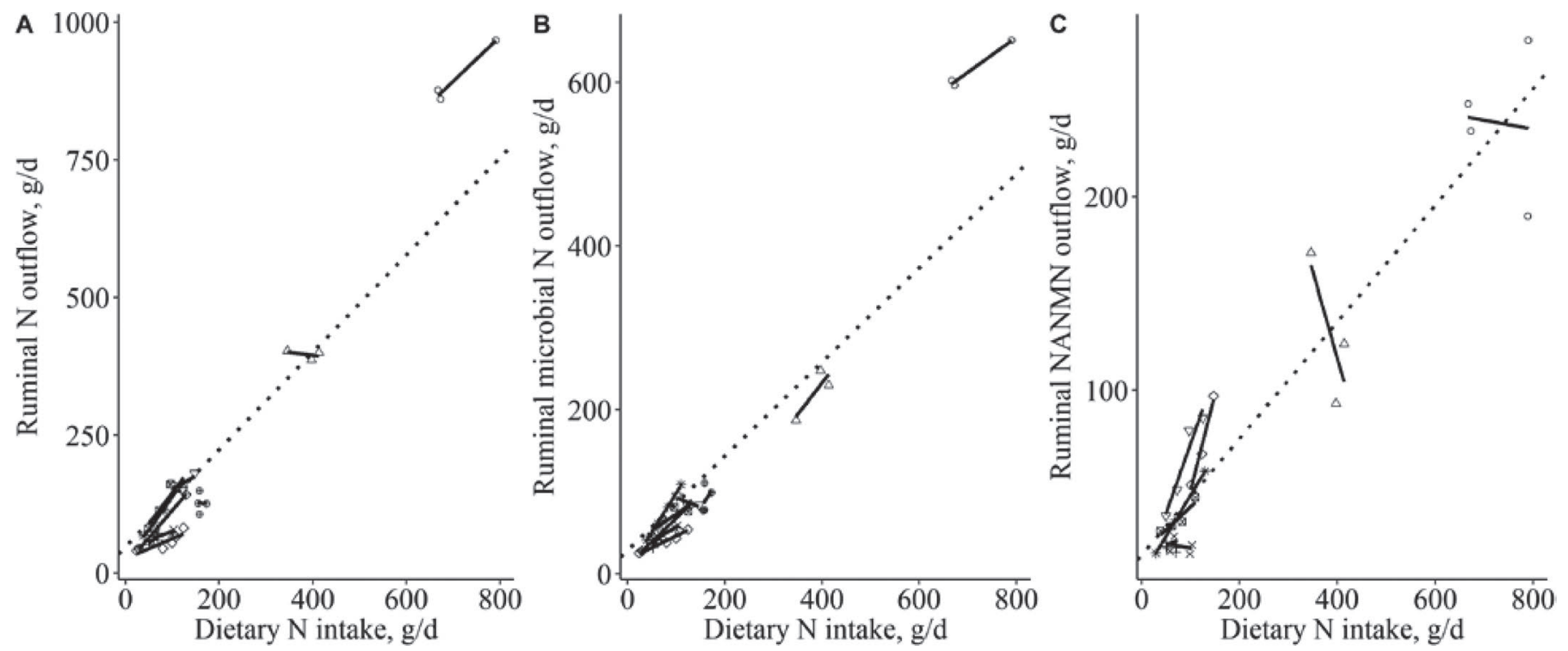

Figure 3. Relationships between observed dietary $\mathrm{N}$ intake and ruminal N, microbial N, and nonammonia, nonmicrobial N (NANMN) outflow. The solid lines represent the results of linear regression for individual studies. The dotted line indicates the global regression for the full data set. Study effect was included as a random variable in the global regression model. (A) Ruminal N outflow (g of N/d) versus dietary N intake ( $\mathrm{g}$ of $\mathrm{N} / \mathrm{d}): \mathrm{Y}=47.04+0.88 \mathrm{X}\left(\mathrm{R}_{\mathrm{m}}^{2}=0.78\right.$ and $\left.\mathrm{R}_{\mathrm{c}}{ }_{\mathrm{c}}=0.99\right) ;(\mathrm{B})$ ruminal microbial $\mathrm{N}$ outflow $(\mathrm{g}$ of $\mathrm{N} / \mathrm{d})$ versus dietary $\mathrm{N}$ intake $(\mathrm{g}$ of $\mathrm{N} / \mathrm{d}): \mathrm{Y}=28.50+0.57 \mathrm{X}\left(\mathrm{R}_{\mathrm{m}}^{2}=0.72\right.$ and $\left.\mathrm{R}_{\mathrm{c}}^{2}=0.99\right) ;(\mathrm{C})$ ruminal NANMN outflow $(\mathrm{g}$ of $\mathrm{N} / \mathrm{d})$ versus dietary $\mathrm{N}$ intake $(\mathrm{g}$ of $\mathrm{N} / \mathrm{d}): \mathrm{Y}=14.77$ $+0.30 \mathrm{X}\left(\mathrm{R}_{\mathrm{m}}^{2}=0.88\right.$ and $\left.\mathrm{R}_{\mathrm{c}}^{2}=0.90\right)$, where $\mathrm{R}_{\mathrm{m}}^{2}$ is marginal $\mathrm{R}^{2}$, which represents the proportion of variance that can be explained by the fixed effect, and $\mathrm{R}^{2}{ }_{\mathrm{c}}$ is conditional $\mathrm{R}^{2}$, which indicates the proportion of variance that can be explained by the fixed effect plus the random effect.

estimated at $6.8 \pm 0.3 \mathrm{~m} M$ compared with the prior value of $0.2 \mathrm{~m} M$ (Hanigan et al., 2013), and the newly introduced ammonia sensitivity exponent $\left(X_{E A m}\right)$ was estimated at $8.55 \pm 0.23 \mathrm{~mol} / \mathrm{mol} ; K_{A m M i, R u m}$ indicates the concentration of ruminal ammonia when microbial growth is half of the maximal rate. Although the work of Satter and Slyter (1974) demonstrated that microbial growth was maximized at an ammonia concentration of $1.5 \mathrm{~m} M$, Reynal and Broderick (2005) suggested that ammonia concentrations $>8.4 \mathrm{~m} M$ might be needed to maximize microbial protein synthesis. Hanigan et al. (2013) previously solved for a half-maximal concentration of $0.2 \mathrm{mM}$, but the ammonia concentrations predicted previously by the model were very biased, leading to the current work. The derived value for $X_{E A m}$ was much greater than expected, indicating that there is a robust sensitivity of ammonia concentrations to microbial growth and it was better defined by the data, resulting in improved predictions of microbial growth. At ammonia concentrations of 5 and $10 \mathrm{mM}, 67.3$ and $96.4 \%$ of maximal growth would be achieved with $K_{A m M i R u m}$ at $6.8 \mathrm{~m} M$ using the revised equation, which was consistent with the result reported by Reynal and Broderick (2005). Fitting the data herein decreased prediction errors of ruminal microbial $\mathrm{N}$ outflow from an RMSE of 43.5 to $32.3 \%$, because of a reduced slope bias from 13.1 to $1.8 \%$ (Table 2). However, the prediction error for ruminal microbial $\mathrm{N}$ outflow exhibited by the unmodified model was greater than observed by Hanigan et al. (2013), possibly because of the limited observations herein. Additional parameterization work should be undertaken using a larger data set.

The mass action rate constant $\left(K_{A m, \text { RumBld }}\right)$ used to represent ammonia absorption (Baldwin, 1995) solved for a value of $5.76 \mathrm{~d}^{-1}$ compared with the prior value of $10.44 \mathrm{~d}^{-1}$, which reduced the mean prediction bias. The model simulation indicated that predicted ruminal ammonia $\mathrm{N}$ absorption rates averaged $28 \%$ of incremental dietary $\mathrm{N}$ intake with a range from 15 to $45 \%$. Lapierre et al. (2005) and Firkins and Reynolds (2005) reported that net portal-drained viscera ammonia- $\mathrm{N}$ absorption represented between 30 and $42 \%$ of dietary $\mathrm{N}$ intake. The reduction in the rate constant was partially due to consideration of ammonia outflow from the rumen in the liquid fraction. In the absence of such a consideration, all ammonia leaving the rumen was by absorption. Ammonia- $\mathrm{N}$ passage averaged $0.9 \mathrm{~mol} / \mathrm{d}$, which is $20 \%$ of the total ammonia- $\mathrm{N}$ flux and $6 \%$ of total $\mathrm{N}$ outflow. This was consistent with observed proportions of 4 to $10 \%$ of total $\mathrm{N}$ flow from the rumen (Chan et al., 1997; Zhu et al., 1997). This change in representation had no effect on total ammonia absorption because it was assumed that ruminal ammonia outflow was completely absorbed (Smith, 1969).

The RMSE for total ruminal $\mathrm{N}$ outflow (a sum of microbial $\mathrm{N}$, undegraded feed protein $\mathrm{N}$, ammonia-N 
UREA AND AMMONIA N RECYCLING IN THE MOLLY COW MODEL

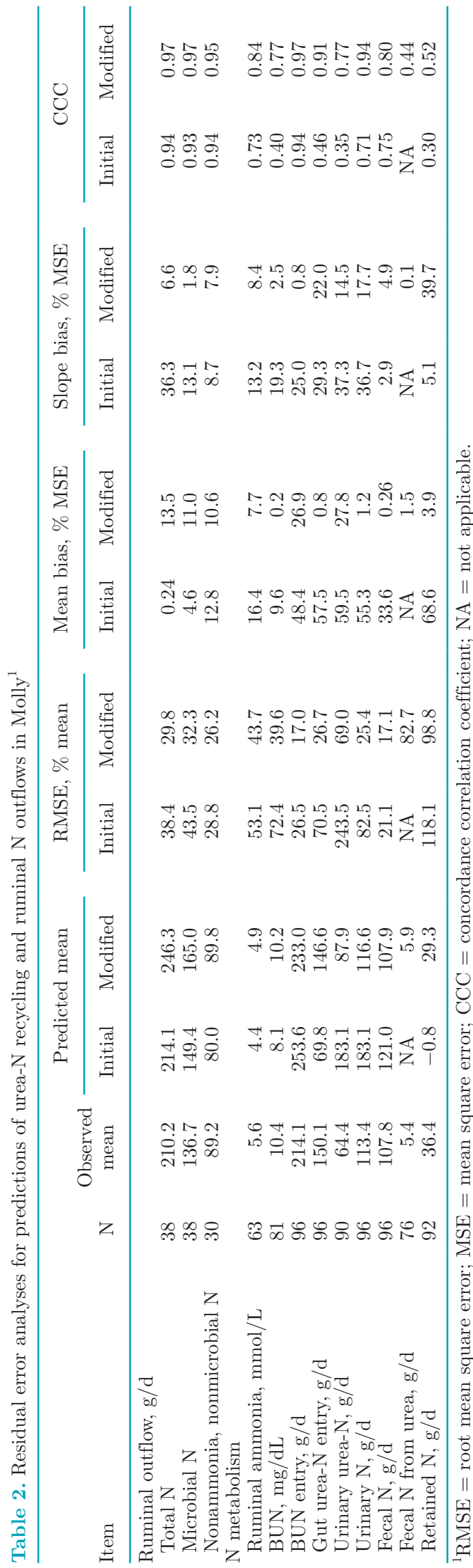

and AA-N) was reduced from 38.4 to $29.8 \%$ after model changes and parameterization, and CCC increased from 0.94 to 0.97 (Table 2). The mean bias was increased from 0.24 to $13.5 \%$. However, the slope bias was substantially decreased from 36.3 to $6.6 \%$. Several high-leverage points were observed by examination of the residuals' plots, which contributed to the moderate mean bias (Figure 4).

\section{Blood Urea Metabolism}

The RMSE of blood urea concentrations was substantially decreased from 72.4 to $39.6 \%$ and CCC increased from 0.40 to 0.77 , suggesting that both accuracy and precision of predicted blood urea concentrations were enhanced. Mean bias and slope bias were decreased from 9.6 to $0.2 \%$, and 19.3 to $2.5 \%$, primarily due to improved representations of ruminal ammonia metabolism and blood urea metabolism.

Predictions of blood urea-N entry exhibited an RMSE of $17.0 \%$ (26.9\% mean bias and $0.8 \%$ slope bias) and a CCC of 0.97, indicating that the model represented the mechanisms of hepatic ureagenesis properly. Blood urea- $\mathrm{N}$ entry accounted for approximately $64 \%$ of incremental dietary $\mathrm{N}$ intake (Figure 5), suggesting that hepatic ureagenesis is a major crossroad in terms of whole-body $\mathrm{N}$ exchange. In the current work, we added representations of intestinal urea entry, which altered urea distribution and ammonia absorption from the digestive tract. Previous studies indicated that some blood urea was recycled to the lower gut and captured in microbial protein (Nolan and Leng, 1972; Bailey et al., 2012a). Considering there is less fermentable energy for microbial growth in the hindgut than in the rumen, we assumed that $25 \%$ of recycled urea to the intestine was utilized for microbial protein synthesis. The remainder was excreted in feces as ammonia or reabsorbed from the hindgut. Changing the assumption from 25 to $50 \%$ resulted in a $4 \%$ decrease in blood urea entry and gut urea entry and a $6 \%$ increase of fecal $\mathrm{N}$ output, indicating that the model was not tremendously sensitive to this assumption. Model simulation results indicated that approximately 48 to $67 \%$ of the urea recycled to the gut flows into the rumen largely depending on diets, suggesting that the addition of intestinal urea entry was important in that it allowed contributions to $\mathrm{N}$ cycling without requiring entry of urea into the rumen.

Amino acid catabolism is another source of hepatic ureagenesis. Approximately 15 to $35 \%$ of absorbed AA are utilized as an energy source by gut tissues on a daily basis (Lobley and Lapierre, 2003; Arriola Apelo et al., 2014). Daily use of EAA by the liver can be as high as 35 to $50 \%$ of that absorbed when high-protein 
diets are fed or milk production is low (Lapierre et al., 2005). Of those cleared by the splanchnic tissues, the majority are catabolized and converted to ammonia and carbon skeletons (Hanigan et al., 2004; Lapierre et al., 2005). To prevent hyperammonemia, ammonia is converted to urea in the liver. Although the mechanisms of AA catabolism are simulated in the model (Baldwin, 1995; Hanigan et al., 2009), limited data are available to evaluate the accuracy of AA-N contributions to urea synthesis. Retained $\mathrm{N}$ reported by the investigators represents the fraction of absorbed $\mathrm{N}$ that is converted to lean body tissue growth or lost in scurf. Comparison of these values to lean body tissue deposition predicted by the model indicated an RMSE of $118.1 \%$ with a mean bias of $68.6 \%$ and a slope bias of $5.1 \%$ before the modifications and reparameterizations (Table 2). The predicted retained $\mathrm{N}$ was $-0.8 \mathrm{~g} / \mathrm{d}$, suggesting the animals were essentially in $\mathrm{N}$ balance during the experimental periods. However, the mean of the observed N retention was $36.4 \mathrm{~g} / \mathrm{d}$. We addressed this problem simultaneously with urea recycling by fitting the maximal rate of the AA conversion to body protein $\left(V m_{\text {AaOth, Vis }}, \mathrm{mol} / \mathrm{d}\right)$ to the data. This resulted in an increase in the parameter from 223 to $273.8 \mathrm{~g} / \mathrm{d}$, resulting in a decreased prediction error for retained $\mathrm{N}$ to an RMSE of $98.8 \%$ with a mean bias of $3.9 \%$ and slope bias of $39.7 \%$, which was an improvement; however, the slope bias suggests that the representation of overall $\mathrm{N}$ balance systematically deviates from observed values.
This error might be due to the accumulation of errors in measured $\mathrm{N}$ balance. Unexplained $\mathrm{N}$ losses, including spilled feed, incomplete recovery of fecal material, and gaseous forms of $\mathrm{N}$ or nitrate formation, contribute to overestimates of $\mathrm{N}$ balance (Firkins and Reynolds, 2005). Additional robust data such as BW gain and body compositions are needed to provide a closer estimate to true $\mathrm{N}$ retention than balance studies.

Reynolds and Kristensen (2008) concluded that increasing dietary $\mathrm{N}$ intake was associated with increased blood urea entry (Figure 5) but the effect of $\mathrm{N}$ intake on gut urea entry was small. However, that is not consistent with the observations herein. As shown in Figure 6, observed gut urea entry linearly increased with dietary $\mathrm{N}$ intake (Figure $6 \mathrm{~A}$ ) and $\mathrm{N}$ intake relative to metabolic BW (Figure 6B). Approximately $64 \%$ of synthesized urea was recycled to the gut lumen (Figure 7A). Model simulations indicated that predicted urea$\mathrm{N}$ recycled to the rumen account for 30 to $54 \%$ of total ruminal ammonia production depending on dietary CP content and RDP proportions, thus representing an important contribution to overall ruminal $\mathrm{N}$ balance.

Observed urinary urea excretion also increased linearly with increased dietary $\mathrm{N}$ intake (Figure 8A) and $\mathrm{N}$ intake relative to metabolic BW (Figure 8B). Approximately $32 \%$ of synthesized urea was eliminated in urine (Figure 7B). Reynolds and Kristensen (2008) observed that fractional gut urea entry and urinary urea-N excretion varied with dietary protein concen-

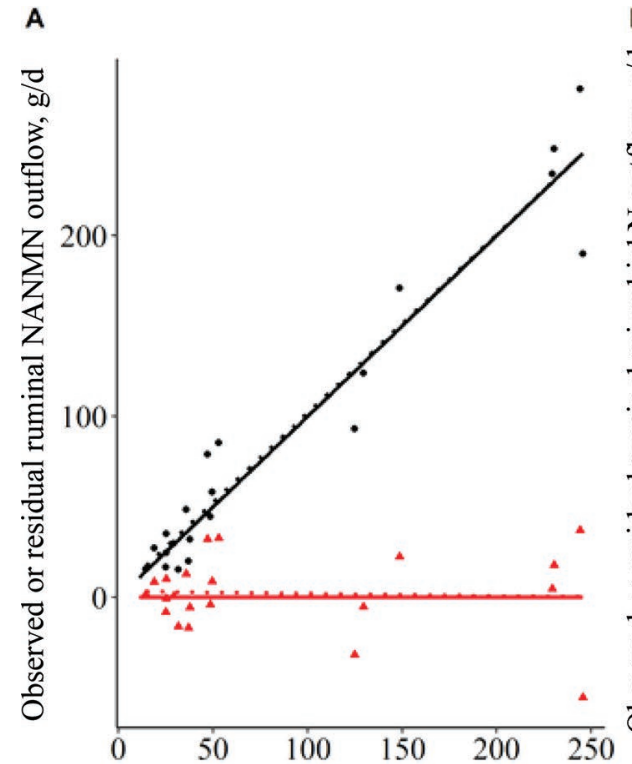

Predicted ruminal NANMN outflow, g/d

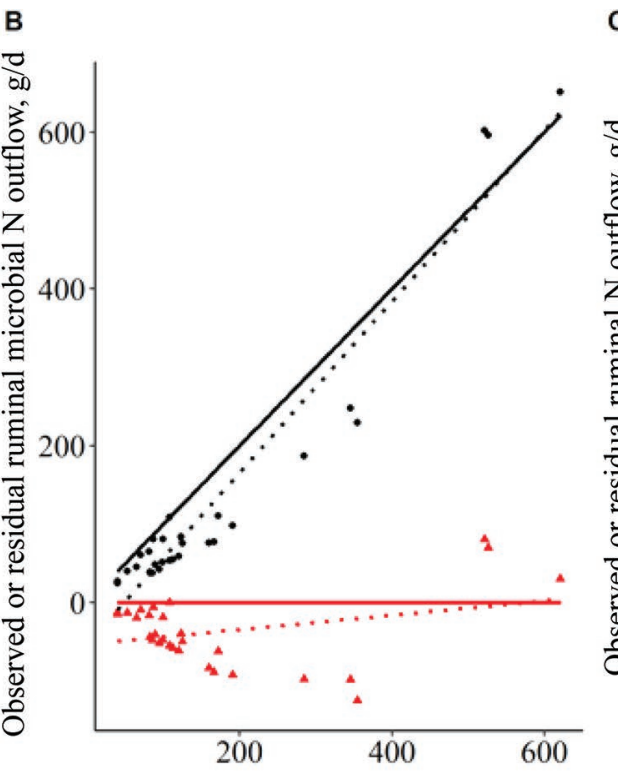

Predicted ruminal microbial $\mathrm{N}$ outflow, g/d
C

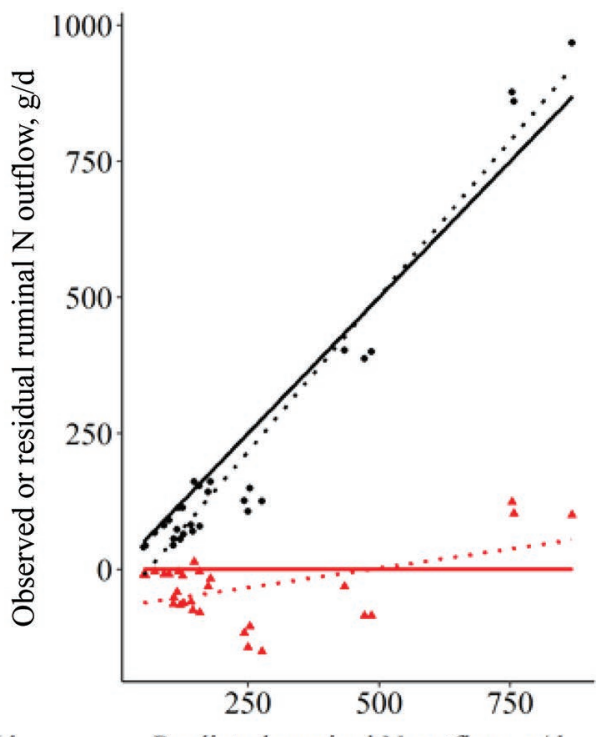

Predicted ruminal $\mathrm{N}$ outflow, $\mathrm{g} / \mathrm{d}$

Figure 4. (A) Observed (, black) or residual ( $\boldsymbol{\Delta}$, red) ruminal nonammonia, nonmicrobial N (NANMN) outflows (g/d) versus predicted flows using the modified model; $(\mathrm{B})$ observed $(\boldsymbol{\bullet}$, black) or residual ( $\boldsymbol{\Delta}$, red) ruminal microbial $\mathrm{N}$ outflow (g/d) versus predicted values using

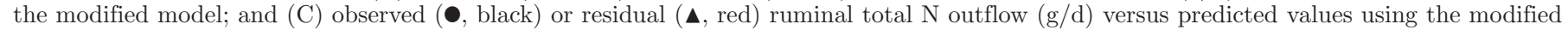
model. The dotted lines represent the line of unity. 
trations in a reciprocal manner. Similar results were found in the current work (Figure 6C and Figure 8C), although the relationship was not strong. However, the relations between the fraction of gut urea entry or urinary urea excretion with dietary protein concentration are easily misleading, because high dietary protein concentration does not necessarily equate to high protein intake. When the fractional rates were regressed on dietary $\mathrm{N}$ intake with respect to metabolic BW, gut entry decreased quadratically, whereas urinary excretion increased quadratically (Figure 6D and Figure 8D), but these relationships are poorly defined by the data. Thus, it seems the best indicator of $\mathrm{N}$ recycling to the gut is simply the amount of urea entering blood. But this overall rate will be modified to the extent that ruminal ammonia concentrations control urea entry. Diets that are low in degradable $\mathrm{N}$ and high in fermentable carbohydrate can be expected to pull a larger fraction of synthesized urea back into the rumen compared with those generating high ruminal ammonia concentrations and with low fermentability.

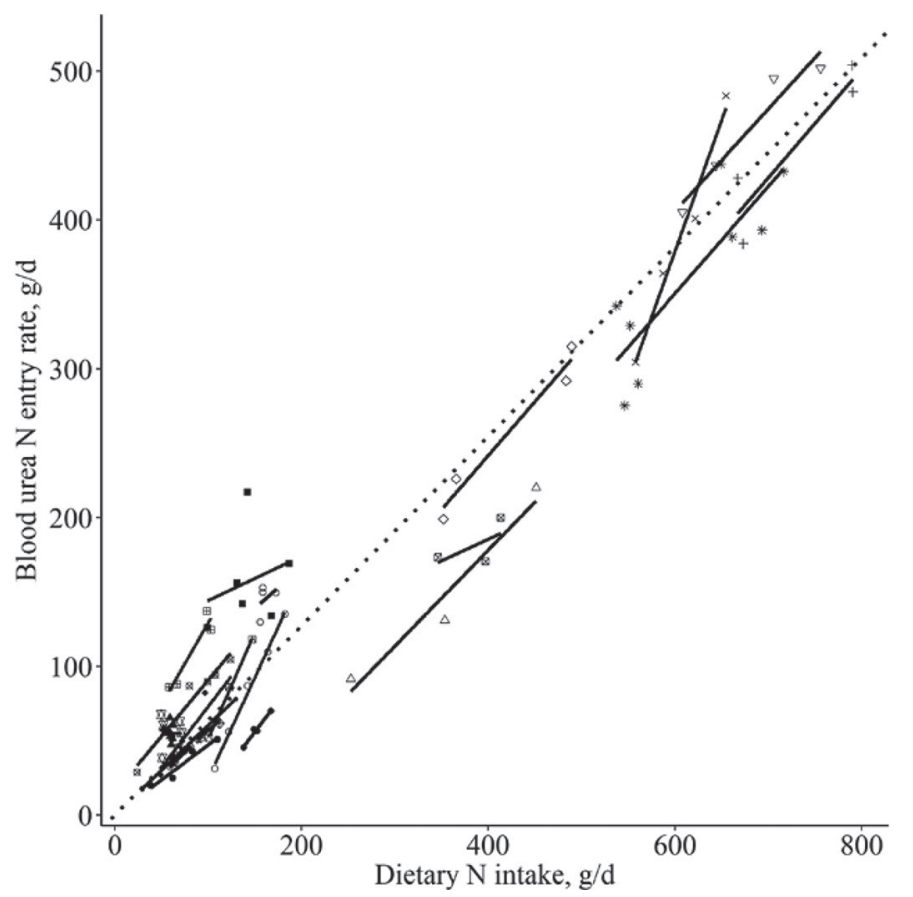

Figure 5. Relationship between observed dietary $\mathrm{N}$ intake ( $\mathrm{g}$ of $\mathrm{N} / \mathrm{d}$ ) and observed urea-N entry rate $(\mathrm{g}$ of $\mathrm{N} / \mathrm{d})$. Solid lines represent the results of linear regression for individual studies. The dotted line indicates the global regression for the full data set. Study effect was included as a random variable in the global regression model. The regression model for the whole data set was $\mathrm{Y}=0.23+0.64 \mathrm{X}\left(\mathrm{R}_{\mathrm{m}}^{2}=\right.$ 0.93 and $\left.R_{c}^{2}=0.98\right)$, where $R_{m}^{2}$ is marginal $R^{2}$, which represents the proportion of variance that can be explained by the fixed effect, and $\mathrm{R}_{\mathrm{c}}^{2}$ is conditional $\mathrm{R}^{2}$, which indicates the proportion of variance that can be explained by the fixed effect plus the random effect.

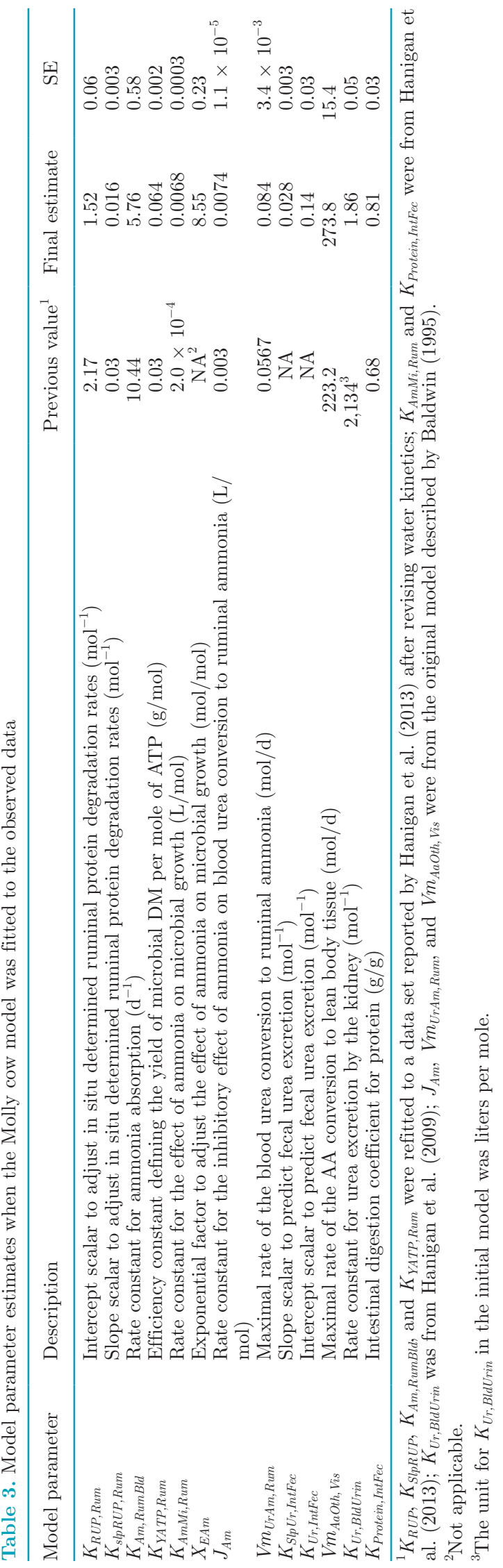

Journal of Dairy Science Vol. 102 No. 6, 2019 

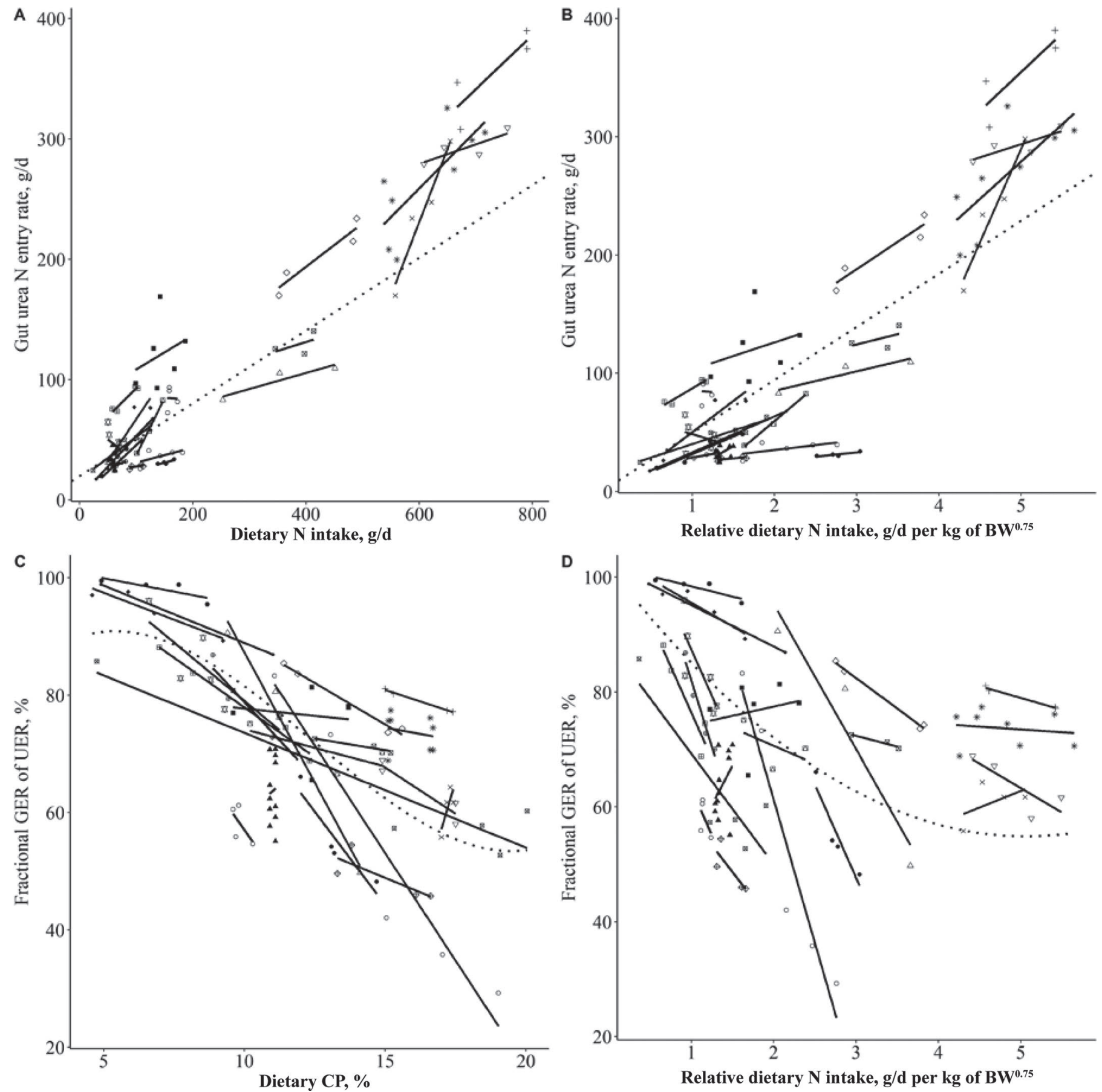

Figure 6. Relationships between observed dietary protein and observed gut urea entry. The solid lines represent the results of linear regression for individual studies. The dotted line indicates the global regression for the full data set. Study effects were included as a random variable in the global regression model. (A) Gut urea- $\mathrm{N}$ entry rate $(\mathrm{g}$ of $\mathrm{N} / \mathrm{d})$ versus dietary $\mathrm{N}$ intake $(\mathrm{g}$ of $\mathrm{N} / \mathrm{d}): \mathrm{Y}=9.49+0.41 \mathrm{X}\left(\mathrm{R}_{\mathrm{m}}^{2}=0.90\right.$ and $\left.\mathrm{R}_{\mathrm{c}}^{2}=0.97\right)$; (B) gut urea-N entry rate $\left(\mathrm{g}\right.$ of $\mathrm{N} / \mathrm{d}$ ) versus dietary $\mathrm{N}$ intake relative to metabolic $\mathrm{BW}\left(\mathrm{g} / \mathrm{d}\right.$ per $\mathrm{kg}$ of $\left.\mathrm{BW} \mathrm{W}^{0.75}\right): \mathrm{Y}=4.49+44.90 \mathrm{X}$ $\left(\mathrm{R}_{\mathrm{m}}^{2}=0.61\right.$ and $\left.\mathrm{R}_{c}^{2}=0.95\right)$; (C) fractional gut urea entry rate (GER) of blood urea entry rate (UER) $(\%)$ versus dietary $\mathrm{CP}(\%): \mathrm{Y}=70.17$ $+0.027 \mathrm{X}^{3}-1.0 \mathrm{X}^{2}+8.45 \mathrm{X}\left(\mathrm{R}_{\mathrm{m}}^{2}=0.49\right.$ and $\left.\mathrm{R}_{\mathrm{c}}^{2}=0.88\right)$; and (D) fractional GER of blood UER (\%) versus dietary $\mathrm{N}$ intake relative to metabolic BW (g/d per kg of $\left.\mathrm{BW}^{0.75}\right): \mathrm{Y}=101.83+1.83 \mathrm{X}^{2}-18.54 \mathrm{X}\left(\mathrm{R}_{\mathrm{m}}^{2}=0.34\right.$ and $\left.\mathrm{R}_{\mathrm{c}}^{2}=0.88\right)$, where $\mathrm{R}_{\mathrm{m}}^{2}$ is marginal $\mathrm{R}^{2}$, which represents the proportion of variance that can be explained by the fixed effect, and $\mathrm{R}_{\mathrm{c}}^{2}$ is conditional $\mathrm{R}^{2}$, which indicates the proportion of variance that can be explained by the fixed effect plus the random effect. 

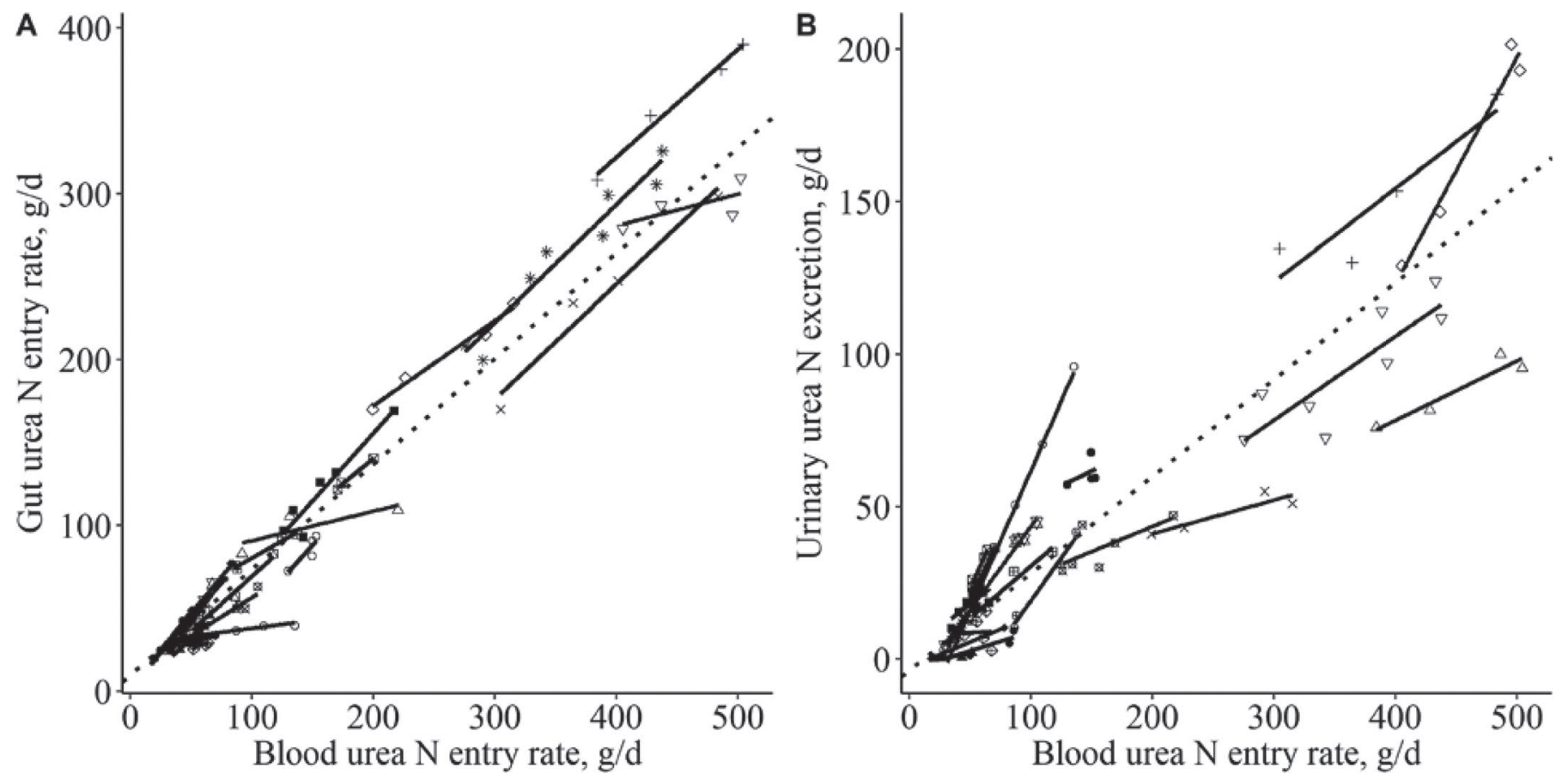

Figure 7. Relationships between observed blood urea entry rate ( $\mathrm{g}$ of $\mathrm{N} / \mathrm{d}$ ) and observed gut urea entry rate or urinary urea-N excretion ( $\mathrm{g}$ of $\mathrm{N} / \mathrm{d}$ ). The solid lines represent the results of linear regression for individual studies. The dotted line indicates the global regression for the full data set. (A) Gut urea entry rate versus blood urea entry: $\mathrm{Y}=10.03+0.64 \mathrm{X}\left(\mathrm{R}_{\mathrm{m}}^{2}=0.94\right.$ and $\left.\mathrm{R}_{\mathrm{c}}^{2}=0.99\right)$; $(\mathrm{B})$ urinary urea-N excretion versus blood urea entry rate: $Y=-3.68+0.32 X\left(R_{m}^{2}=0.82\right.$ and $\left.R_{c}^{2}=0.96\right)$, where $R_{m}^{2}$ is marginal $R^{2}$, which represents the proportion of variance that can be explained by the fixed effect, and $R_{c}^{2}$ is conditional $R^{2}$, which indicates the proportion of variance that can be explained by the fixed effect plus the random effect. The study effect was considered as a random variable.

\section{Urinary N Excretion}

Urinary $\mathrm{N}$ is mainly derived from urea at 55 to $62 \%$ of urinary N (Gonda and Lindberg, 1994), with lesser contributions from purine derivatives and ammonia. Altering the representation of urea excretion to be a function of pool size rather than concentration and refitting to the data resulted in a fractional excretion rate of $1.86 \mathrm{~d}^{-1}$, a substantial reduction in RMSE from 243.5 to $69.0 \%$, and an increase in CCC from 0.35 to 0.77 , suggesting a considerable improvement associated with the change in representation. However, the precision of predicted urinary urea was still poor. As urinary $\mathrm{N}$ is likely collected with minimal error and not subject to variation in sampling, it seems likely that a significant proportion of the remaining variance reflects biological mechanisms and is thus potentially explainable. Several studies have indicated that renal processes such as the glomerular filtration rate and urea recycling from the glomerular filtrate are affected by CP (Rabinowitz et al., 1973; Eriksson and Valtonen, 1982) and $\mathrm{NaCl}$ (Godwin and Williams, 1984). Residual analyses indicated that urinary urea residuals were positively correlated with $\mathrm{CP}$ intake $(P<0.05)$, suggesting that urinary urea excretion was underestimated when highprotein diets were fed. Spek et al. (2013) demonstrated that urinary urea excretion tended to be negatively related to the renal urea reabsorption ratio for highprotein diets, whereas no significant effect was observed for low-protein diets. Our results were consistent with their report, suggesting that the addition of inhibitory effects of protein on urea reabsorption might improve the representations of urinary urea excretion. There was no correlation between urinary urea residuals and ash intake, which was consistent with previous studies, as the effects of dietary $\mathrm{NaCl}$ on urinary urea excretion were not significant (Spek et al., 2012, 2013). However, the amount of explained variation in urinary urea excretion increased $8 \%$ when $\mathrm{NaCl}$ was included in the model (Spek et al., 2013). Sorting out these potential effects will require a concerted effort to collect such information to build a more complicated model to reflect the effects of $\mathrm{CP}$ and $\mathrm{NaCl}$ on renal mechanisms of urea absorption and excretion.

Adding representations of the excretion of purine derivatives in urine improved both accuracy and precision of urinary $\mathrm{N}$ predictions from a CCC of 0.71 to 0.94 and substantially decreased RMSE from 82.5 to $25.4 \%$. 

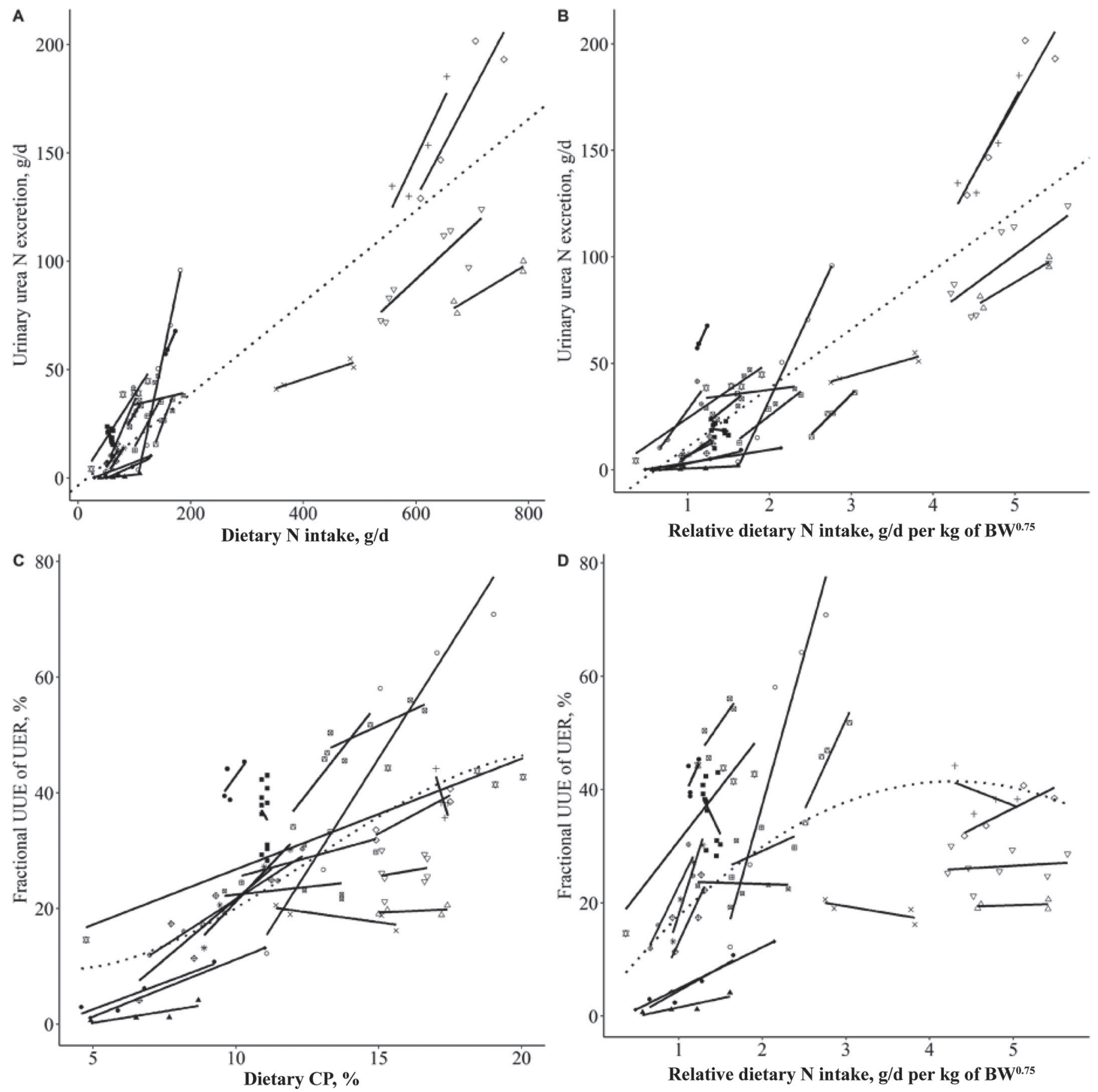

Figure 8. Relationships between dietary protein and urinary urea excretion. The solid lines represent the results of linear regression for individual studies. The dotted line indicates the global regression for the full data set. Study effect was included as a random variable in the global regression model. (A) Urinary urea-N excretion (g of N/d) versus dietary N intake $\left(\mathrm{g}\right.$ of N/d): $\mathrm{Y}=-3.44+0.21 \mathrm{X}\left(\mathrm{R}_{\mathrm{m}}^{2}=0.79\right.$ and $\mathrm{R}^{2}{ }_{\mathrm{c}}=$ $0.96)$; (B) urinary urea- $\mathrm{N}$ excretion $\left(\mathrm{g}\right.$ of $\mathrm{N} / \mathrm{d}$ ) versus dietary $\mathrm{N}$ intake relative to metabolic $\mathrm{BW}\left(\mathrm{g} / \mathrm{d}\right.$ per $\mathrm{kg}_{\mathrm{g}}$ of $\left.\mathrm{BW}^{0.75}\right): \mathrm{Y}=-16.74+27.60 \mathrm{X}$ $\left(\mathrm{R}_{\mathrm{m}}^{2}=0.72\right.$ and $\left.\mathrm{R}_{\mathrm{c}}^{2}=0.95\right)$; $(\mathrm{C})$ fractional urinary urea excretion (UUE) of blood urea entry rate (UER) $(\%)$ versus dietary $\mathrm{CP}(\%)$ : $\mathrm{Y}=$ $16.06-0.014 \mathrm{X}^{3}+0.54 \mathrm{X}^{2}-3.60 \mathrm{X}\left(\mathrm{R}_{\mathrm{m}}^{2}=0.42\right.$ and $\left.\mathrm{R}_{\mathrm{c}}^{2}=0.86\right)$; and (D) fractional UUE of blood UER (\%) versus dietary $\mathrm{N}$ intake relative to metabolic BW (g/d per kg of BW $\left.{ }^{0.75}\right): \mathrm{Y}=1.03-2.20 \mathrm{X}^{2}+18.85 \mathrm{X}\left(\mathrm{R}_{\mathrm{m}}^{2}=0.26\right.$ and $\left.\mathrm{R}_{\mathrm{c}}^{2}=0.85\right)$, where $\mathrm{R}_{\mathrm{m}}^{2}$ is marginal $\mathrm{R}^{2}$, which represents the proportion of variance that can be explained by the fixed effect, and $\mathrm{R}_{\mathrm{c}}^{2}$ is conditional $\mathrm{R}^{2}$, which indicates the proportion of variance that can be explained by the fixed effect plus the random effect. 
The improvement was largely due to removal of mean bias and slope bias, which decreased from 55.3 to $1.2 \%$ and from 36.7 to $17.7 \%$, respectively.

\section{Fecal N Excretion}

Compared with the initial model, several nitrogenous components were considered in the feces, including undigested microbial nucleic acids, microbial protein synthesized in the hindgut, and ammonia generated from fecal urea hydrolysis. Considering that there is no urea pool in the gut, fecal $\mathrm{N}$ generated from urea hydrolysis was simulated as a linear function of intestinal urea entry rate. An intercept scalar $\left(K_{U r . I n t F e c}\right)$ and a slope scalar $\left(K_{S l p U r, I n t F e c}\right)$ were derived to predict fecal excretion of $\mathrm{N}$ derived from urea based on the observed values. The endogenous urea-N loss in feces $\left(K_{U r, \text { IntFec }}\right)$ was 0.14 and the fractional transfer of urea-N entering the gut to feces $\left(K_{S l p U r, I n t F e c}\right)$ was 0.028 . The negligible slope estimate suggests that there was not a linear relationship between intestinal urea entry and fecal $\mathrm{N}$ from catabolized urea, which implies fecal urea- $\mathrm{N}$ excretion was constant among diets as $\mathrm{N}$ intake varied. Because the model does not consider endogenous protein losses, and we fitted these parameters against both fecal urea excretion and total fecal $\mathrm{N}$ output, $K_{U r, I n t F e c}$ could be used to represent total endogenous $\mathrm{N}$ loss in feces, which includes urea, sloughed cells, and enzyme excretions into the gut. As a result, consideration of these additional $\mathrm{N}$ compounds in feces allowed the intestinal digestion coefficient $\left(K_{\text {Protein,IntFec }}\right)$ to more closely reflect true protein digestion at 0.81 compared with the prior value of 0.68 . This digestion coefficient was consistent with studies from monogastric animals. The true ileal digestibility of $\mathrm{N}$ was 76.9 to $78.2 \%$ in growing rats (Donkoh and Moughan, 1994), 75 to $83 \%$ in growing pigs (Furuya and Kaji, 1989; Hess et al., 2000 ), and 75 to $86 \%$ in broiler chickens (Huang et al., 2005; Gabriel et al., 2008). The RMSE for fecal N excretion was slightly decreased from 21.1 to $17.1 \%$, with substantially decreased mean bias from 33.6 to $0.26 \%$, and CCC was increased from 0.75 to 0.80 , suggesting that the changes did improve the representation of total fecal $\mathrm{N}$ output.

\section{Model Simulations}

Having fitted the revised model to the data, we used the model to simulate the effects of several dietary scenarios on $\mathrm{N}$ metabolism. When RUP $\mathrm{N}$ intake was held constant at $192 \mathrm{~g} / \mathrm{d}$ and RDP N intake was increased from 128 to $448 \mathrm{~g} / \mathrm{d}$, predicted microbial $\mathrm{N}$ outflow increased from 136 to $356 \mathrm{~g} / \mathrm{d}$ and, consequently, predicted total $\mathrm{N}$ outflow increased from 361 to 617 $\mathrm{g} / \mathrm{d}$ (Figure 9A). This led to an increase in predicted blood urea-N entry from 136 to $408 \mathrm{~g} / \mathrm{d}$ and increased predicted urinary urea-N excretion from 37 to $195 \mathrm{~g} / \mathrm{d}$ (Figure 9B). Although predicted gut urea-N entry rate increased as dietary RDP N intake increased from 99 to $207 \mathrm{~g} / \mathrm{d}$ (Figure 9B), the proportions of predicted total ammonia that were generated from recycled urea in the rumen decreased continuously from 41 to 30\% (Figure $9 \mathrm{C}$ ), primarily because of the increased ammonia production rate and the inhibitory effect of ammonia on urea transfer from blood to rumen. With increased RDP intake, more AA and peptides are theoretically available for microbial protein synthesis in the rumen, which contributed to decreased proportions of predicted microbial protein $\mathrm{N}$ from ruminal ammonia-N (71 to $65 \%$; Figure 9C). Under this feeding strategy, both the proportion of ammonia degraded from recycled urea and the proportion of ammonia- $\mathrm{N}$ captured into microbial $\mathrm{N}$ were decreased, resulting in decreased apparent ruminal N efficiency from 113 to 96\% (Figure 9D).

When $\mathrm{N}$ intake was held constant at $512 \mathrm{~g} / \mathrm{d}$, increasing RDP proportions from 10 to $90 \%$ resulted in decreased predictions of ruminal NANMN outflow from 369 to $134 \mathrm{~g} / \mathrm{d}$ and increased predictions of ruminal microbial N outflow from 196 to $351 \mathrm{~g} / \mathrm{d}$. However, the decreased NANMN flow was slightly greater than the increase in microbial $\mathrm{N}$ flow, leading to small linear decreases in predicted total ruminal $\mathrm{N}$ outflow from 566 to $488 \mathrm{~g} / \mathrm{d}$ (Figure 10A). As a result, predicted blood urea-N entry was slightly decreased from 309 to $298 \mathrm{~g} / \mathrm{d}$ (Figure 10B), suggesting that blood urea-N entry was relatively insensitive to RDP. When the proportion of RDP increased from 10 to $90 \%$, ruminal ammonia was sufficient to support microbial protein synthesis despite decreased flux of urea- $\mathrm{N}$ into the rumen and increased urinary urea-N excretion (Figure 10B). In this scenario, proportions of predicted ammonia production incorporated from recycled urea decreased from 54 to $29 \%$, as the inhibitory effect of ammonia on ruminal urea entry was exerted, and proportions of predicted rumen microbial $\mathrm{N}$ captured from ammonia- $\mathrm{N}$ decreased from 76 to $66 \%$ (Figure 10C). These changes contributed to decreased apparent ruminal N efficiency from 110 to 94\% (Figure 10D).

\section{CONCLUSIONS}

Major improvements in predictions of ruminal $\mathrm{N}$ metabolism, blood urea metabolism, and urinary N excretion were achieved, including removal of slope bias for predictions of ruminal microbial $\mathrm{N}$ outflow, blood urea concentrations, and fecal $\mathrm{N}$ excretion, and reductions in mean bias for predictions of ruminal ammonia concentrations and urinary N excretion. Predicted blood 
A

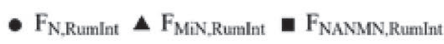

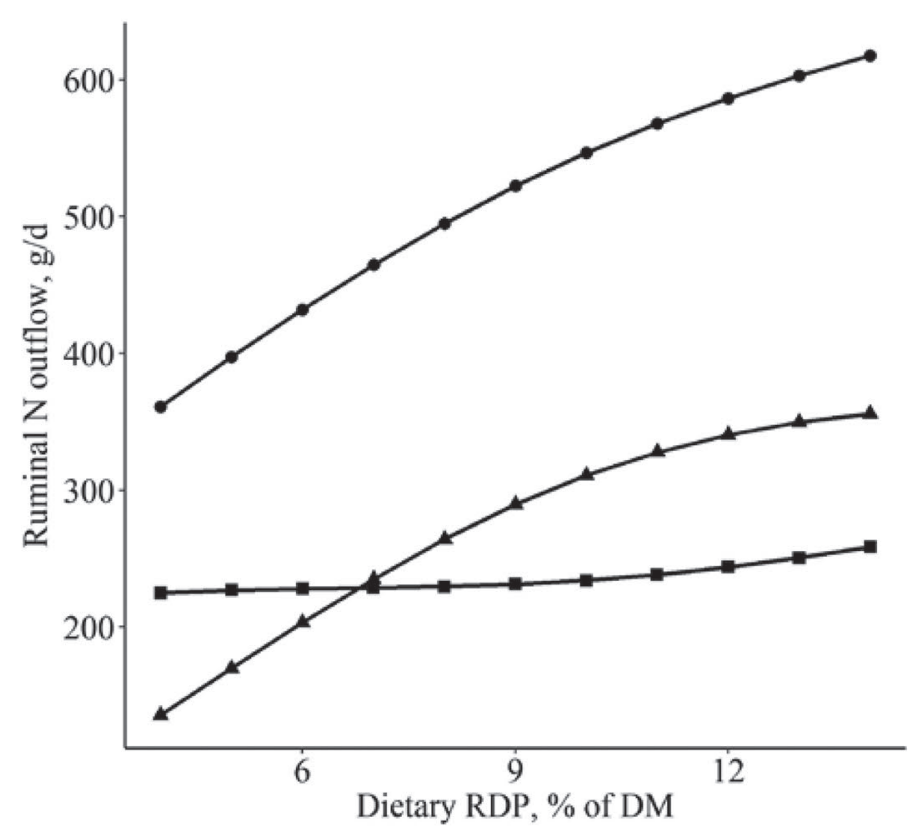

C

- $\mathrm{F}_{\text {AmMi,Ruma }} / \mathrm{F}_{\text {MiN,Rumlnt }} \wedge \mathrm{F}_{\text {Uram,Rum }} / \mathrm{F}_{\text {Am,Rum }}$

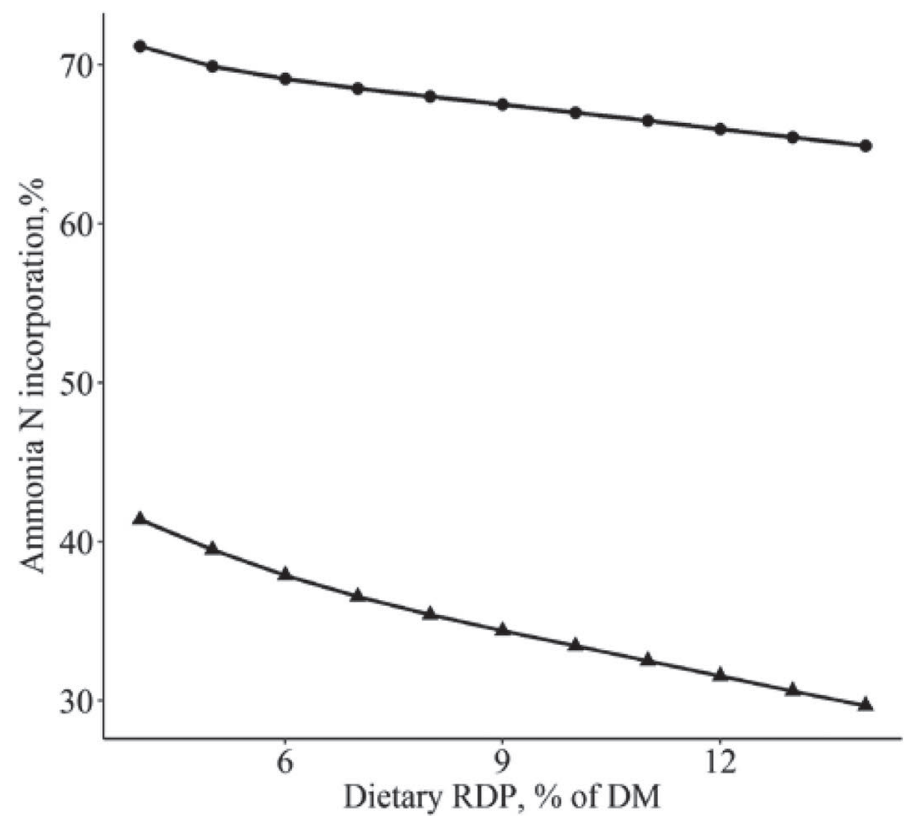

B

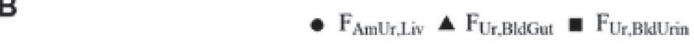

D

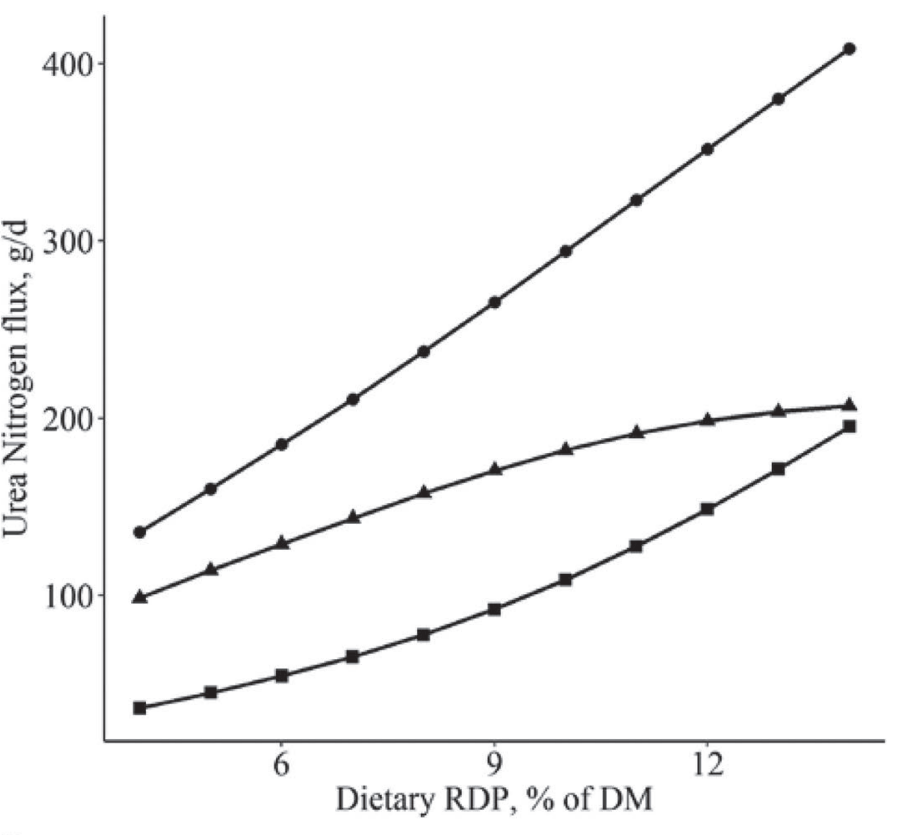

$\bullet\left(\mathrm{F}_{\mathrm{MN}, \text { Rumlnt }}+\mathrm{F}_{\mathrm{NANMN}, \text { Runtm }}\right) / \mathrm{F}_{\mathrm{N}, \mathrm{FaR} \text { um }}$

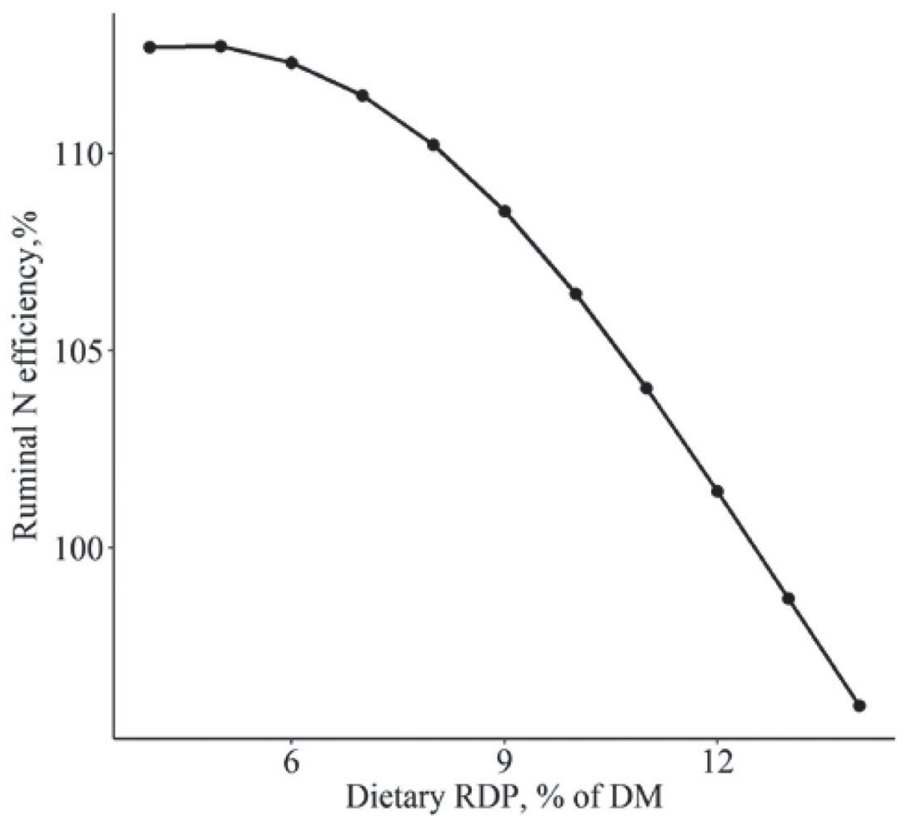

Figure 9. Effects of varying dietary RDP concentrations on model behavior given a constant RUP proportion (6\% of DM); DMI was constant among diets. $F_{N, \text { RumInt }}$ represents ruminal total N outflow; $F_{\text {MiN,RumInt }}$ represents ruminal microbial N outflow; $F_{N A N M N, R u m I n t}$ is ruminal nonammonia, nonmicrobial $\mathrm{N}$ outflow; $F_{A m U r, L i v}$ represents blood urea entry rate; $F_{U r, B l d G u t}$ is gut urea entry rate; $F_{U r, B l d U r i n}$ represents urinary urea excretion; $F_{A m M i, R u m}$ is a flux of ammonia-N converted to microbial protein; $F_{U r A m, R u m}$ is flux of ammonia generated from recycled urea in the rumen; $F_{A m, \text { Rum }}$ is total ammonia production rate; $F_{N, F d R u m}$ is total dietary $\mathrm{N}$ intake.

urea entry and gut urea-N entry exhibited negligible mean bias and slope bias, implying the representation captured the main mechanisms of ruminal urea-N recycling. Hepatic ureagenesis is a major crossroad of whole-body $\mathrm{N}$ exchange. Urea- $\mathrm{N}$ entry into blood accounts for approximately $64 \%$ of dietary $\mathrm{N}$ intake, of which $64 \%$ is recycled to the gut lumen. Depending on the diet, model simulation results indicated that urea 
A

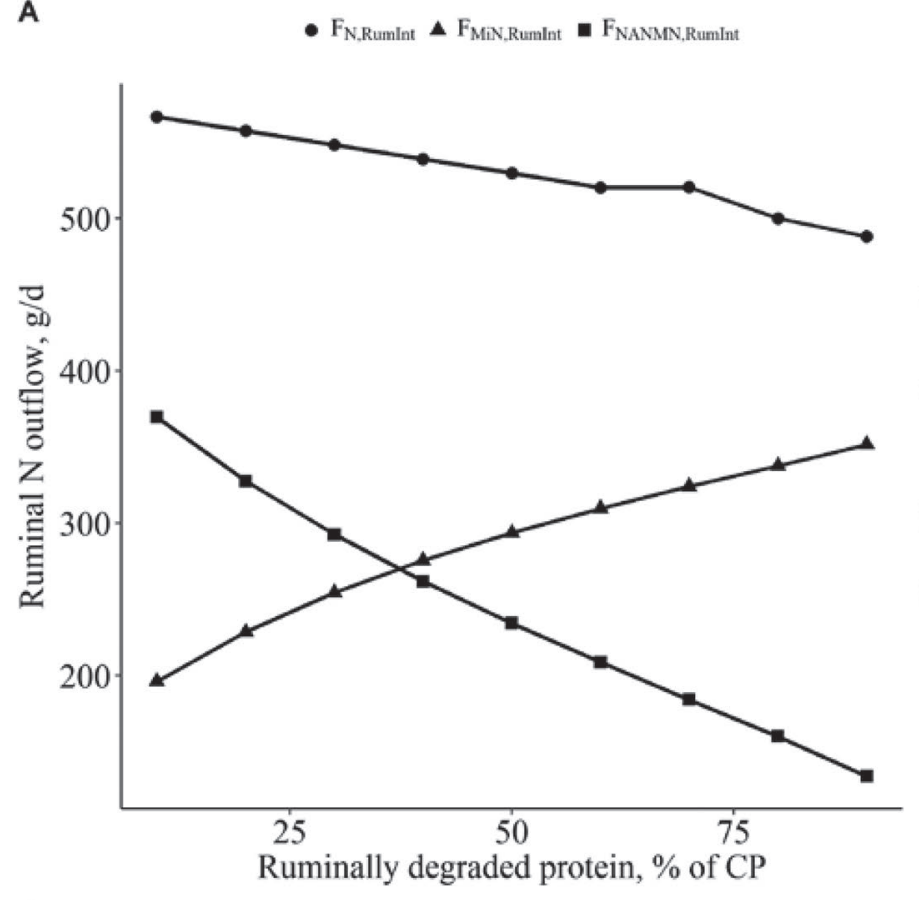

C

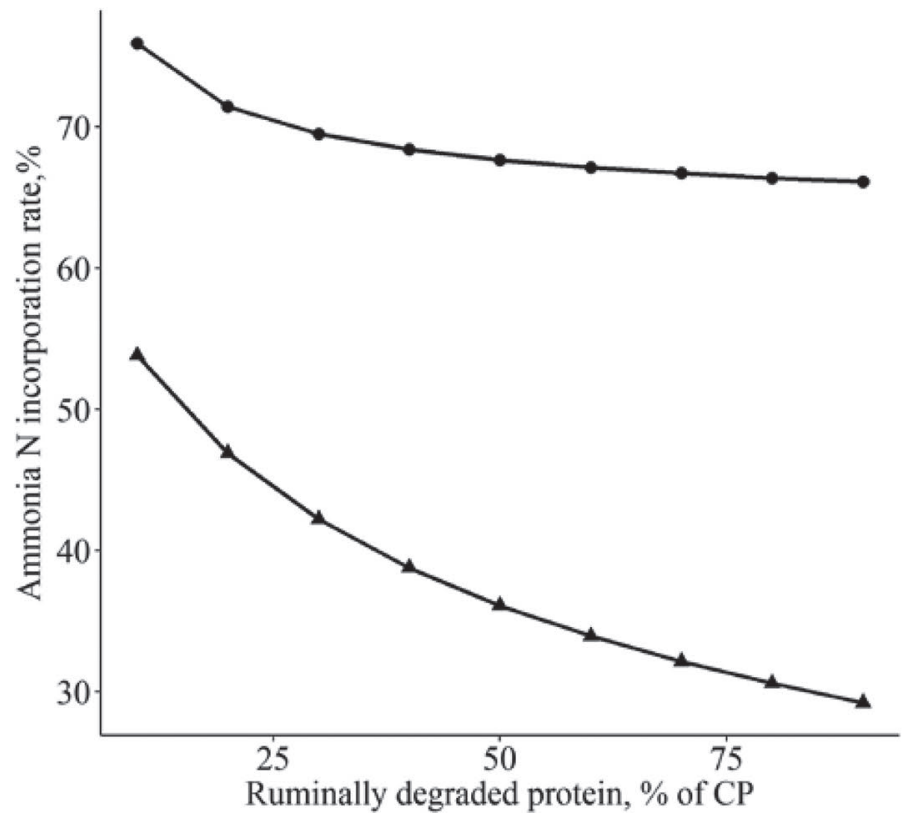

B

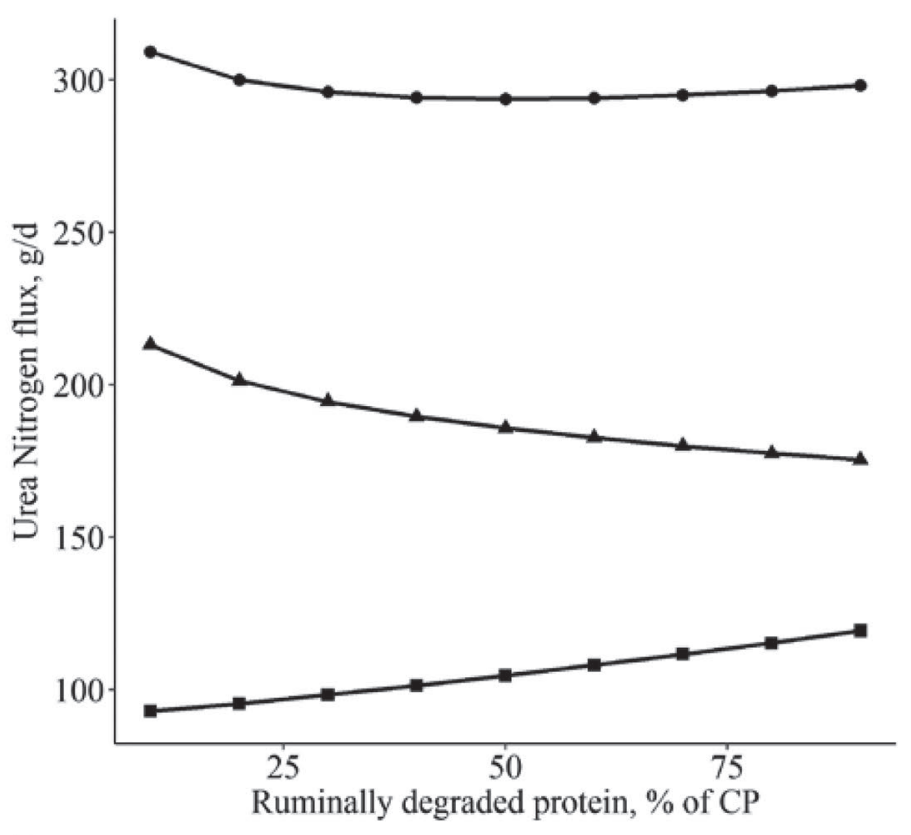

D

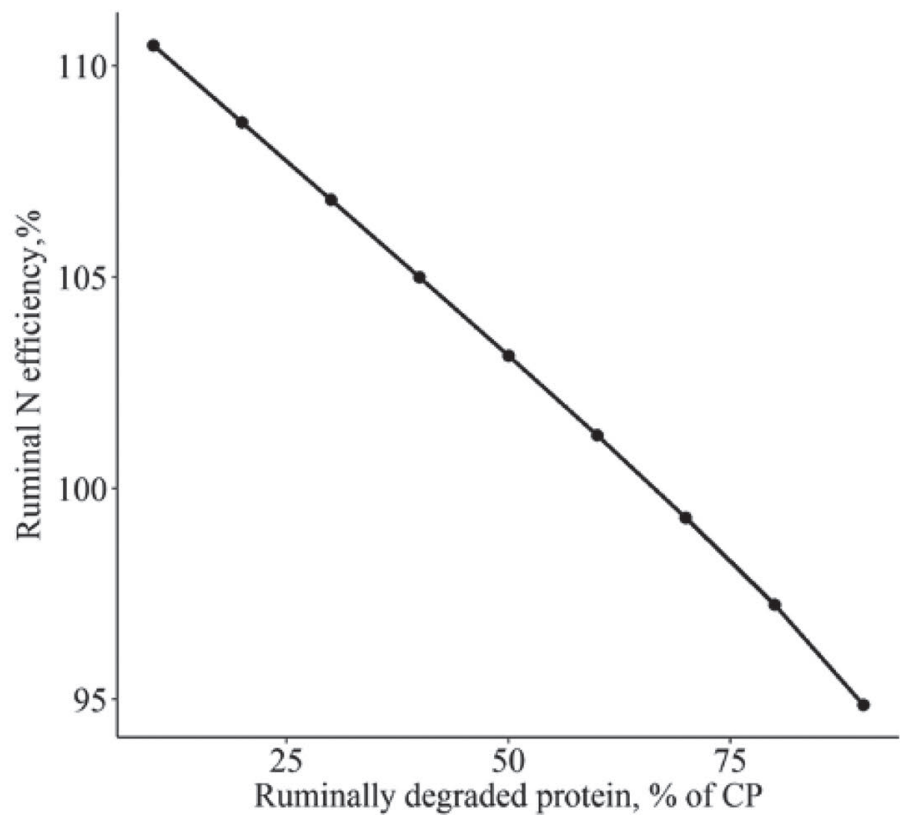

Figure 10. Effects of varying dietary RDP proportions on model behavior given a constant CP concentration (16\% of DM); DMI was constant among diets. $F_{N . R u m I n t}$ represents ruminal total N outflow; $F_{M i N, R u m I n t}$ represents ruminal microbial N outflow; $F_{N A N M N, R u m I n t}$ is ruminal nonammonia, nonmicrobial $\mathrm{N}$ outflow; $F_{A m U r, L i v}$ represents blood urea entry rate; $F_{U r, B l d G u t}$ is gut urea entry rate; $F_{U r, B l d U r i n}$ represents urinary urea excretion; $F_{A m M i, R u m}$ is a flux of ammonia-N converted to microbial protein; $F_{U r A m, \text { Rum }}$ is flux of ammonia generated from recycled urea in the rumen; $F_{A m, R u m}$ is total ammonia production rate; $F_{N, F d R u m}$ is total dietary $\mathrm{N}$ intake.

recycled to the gut accounted for 29 to $54 \%$ of total ruminal ammonia production, and between 65 and $76 \%$ of this ammonia- $\mathrm{N}$ was captured in microbial protein. This equates to $41 \%$ of $\mathrm{N}$ intake returning to the gut, with $60 \%$ entering the rumen. Of this, approximately $70 \%$ is captured in microbial protein, which represents $17 \%$ of $\mathrm{N}$ intake. Thus, this is an important component of the ruminal $\mathrm{N}$ system. Our simulation results sug- 
gested that although feeding moderately low $\mathrm{CP}$ diets with low RDP proportions might decrease microbial protein synthesis in the rumen, this feeding strategy allows greater proportions of feed protein to escape the rumen, greater capture of recycled urea- $\mathrm{N}$ by rumen microbes, and reduced urinary urea excretion. The combination of these resulted in increased total metabolizable protein supply. These predicted outputs would suggest that reducing RDP proportions in a moderately low $\mathrm{CP}$ diet would lead to a substantial change in apparent ruminal $\mathrm{N}$ efficiency, which could improve animal performance in terms of lean growth or milk output.

\section{ACKNOWLEDGMENTS}

This work was funded, in part, by the National Research Initiative Competitive Grants Program from the USDA National Institute of Food and Agriculture (Washington, DC; grant no. 2007-35206-17848) and the Virginia Agricultural Experiment Station and the Hatch Program of the National Institute of Food and Agriculture, USDA; the College of Agriculture and Life Sciences Pratt Endowment at Virginia Tech; and the Alberta Livestock and Meat Agency Ltd. (Edmonton, Alberta, Canada; grant 2015F055R).

\section{REFERENCES}

Archibeque, S. L., J. Burns, and G. Huntington. 2001. Urea flux in beef steers: Effects of forage species and nitrogen fertilization. J. Anim. Sci. 79:1937-1943.

Archibeque, S. L., J. Burns, and G. Huntington. 2002. Nitrogen metabolism of beef steers fed endophyte-free tall fescue hay: Effects of ruminally protected methionine supplementation. J. Anim. Sci. 80:1344-1351.

Arriola Apelo, S. I., J. Knapp, and M. Hanigan. 2014. Invited review: Current representation and future trends of predicting amino acid utilization in the lactating dairy cow. J. Dairy Sci. 97:4000-4017.

Bailey, E. A., E. Titgemeyer, K. Olson, D. Brake, M. Jones, and D. Anderson. 2012a. Effects of ruminal casein and glucose on forage digestion and urea kinetics in beef cattle. J. Anim. Sci. 90:35053514.

Bailey, E. A., E. Titgemeyer, K. Olson, D. Brake, M. Jones, and D. Anderson. 2012b. Effects of supplemental energy and protein on forage digestion and urea kinetics in growing beef cattle. J. Anim. Sci. 90:3492-3504.

Baldwin, R. 1995. Modeling Ruminant Digestion and Metabolism. Springer Science \& Business Media, Berlin, Germany.

Baldwin, R. L., J. France, D. E. Beever, M. Gill, and J. H. Thornley. 1987a. Metabolism of the lactating cow: III. Properties of mechanistic models suitable for evaluation of energetic relationships and factors involved in the partition of nutrients. J. Dairy Res. 54:133-145.

Baldwin, R. L., J. France, and M. Gill. 1987b. Metabolism of the lactating cow: I. Animal elements of a mechanistic model. J. Dairy Res. 54:77-105.

Baldwin, R. L., J. H. Thornley, and D. E. Beever. 1987c. Metabolism of the lactating cow: II. Digestive elements of a mechanistic model. J. Dairy Res. 54:107-131.
Bates, D., M. Mächler, B. Bolker, and S. Walker. 2015. Fitting linear mixed-effects models using lme4. J. Stat. Softw. 67:1-48. https:// doi.org/10.18637/jss.v067.i01.

Batista, E. D., E. Detmann, E. C. Titgemeyer, S. Valadares Filho, R. Valadares, L. Prates, L. Rennó, and M. Paulino. 2016. Effects of varying ruminally undegradable protein supplementation on forage digestion, nitrogen metabolism, and urea kinetics in Nellore cattle fed low-quality tropical forage. J. Anim. Sci. 94:201-216.

Bibby, J., and H. Toutenburg. 1977. Prediction and Improved Estimation in Linear Models. Wiley, Hoboken, NJ.

Brake, D. W., E. Titgemeyer, and M. Jones. 2011. Effect of nitrogen supplementation and zilpaterol- $\mathrm{HCl}$ on urea kinetics in steers consuming corn-based diets. J. Anim. Physiol. Anim. Nutr. (Berl.) 95:409-416.

Brake, D. W., E. Titgemeyer, M. Jones, and D. Anderson. 2010. Effect of nitrogen supplementation on urea kinetics and microbial use of recycled urea in steers consuming corn-based diets. J. Anim. Sci. 88:2729-2740.

Chan, S. C., J. Huber, C. Theurer, Z. Wu, K. Chen, and J. Simas. 1997. Effects of supplemental fat and protein source on ruminal fermentation and nutrient flow to the duodenum in dairy cows. J. Dairy Sci. 80:152-159.

Chibisa, G. E., and T. Mutsvangwa. 2013. Effects of feeding wheat or corn-wheat dried distillers grains with solubles in low-or high-crude protein diets on ruminal function, omasal nutrient flows, urea-N recycling, and performance in cows. J. Dairy Sci. 96:6550-6563.

Davies, K., J. McKinnon, and T. Mutsvangwa. 2013. Effects of dietary ruminally degradable starch and ruminally degradable protein levels on urea recycling, microbial protein production, nitrogen balance, and duodenal nutrient flow in beef heifers fed low crude protein diets. Can. J. Anim. Sci. 93:123-136.

Donkoh, A., and P. Moughan. 1994. The effect of dietary crude protein content on apparent and true ileal nitrogen and amino acid digestibilities. Br. J. Nutr. 72:59-68.

Eriksson, L., and M. Valtonen. 1982. Renal urea handling in goats fed high and low protein diets. J. Dairy Sci. 65:385-389.

Firkins, J., and C. Reynolds. 2005. Whole animal nitrogen balance in cattle. Pages 167-186 in Nitrogen and Phosphorus Nutrition of Cattle: Reducing the Environmental Impact of Cattle Operations. E. Pfeffer and A. Hristov, ed. CAB International, Cambridge, MA.

Furuya, S., and Y. Kaji. 1989. Estimation of the true ileal digestibility of amino acids and nitrogen from their apparent values for growing pigs. Anim. Feed Sci. Technol. 26:271-285.

Gabriel, I., M. Lessire, H. Juin, J. Burstin, G. Duc, L. Quillien, J. Thibault, M. Leconte, J. Hallouis, and P. Ganier. 2008. Variation in seed protein digestion of different pea (Pisum sativum L.) genotypes by cecectomized broiler chickens: 1 . Endogenous amino acid losses, true digestibility and in vitro hydrolysis of proteins. Livest. Sci. 113:251-261.

Godwin, I. R., and V. Williams. 1984. Renal control of plasma urea level in sheep: The diuretic effect of urea, potassium and sodium chloride. Q. J. Exp. Physiol. 69:49-59.

Gonda, H. L., and J. E. Lindberg. 1994. Evaluation of dietary nitrogen utilization in dairy cows based on urea concentrations in blood, urine and milk, and on urinary concentration of purine derivatives. Acta Agric. Scand. A Anim. Sci. 44:236-245.

Gozho, G. N., M. Hobin, and T. Mutsvangwa. 2008. Interactions between barley grain processing and source of supplemental dietary fat on nitrogen metabolism and urea-nitrogen recycling in dairy cows. J. Dairy Sci. 91:247-259.

Gregorini, P., P. Beukes, G. Waghorn, D. Pacheco, and M. Hanigan. 2015. Development of an improved representation of rumen digesta outflow in a mechanistic and dynamic model of a dairy cow. Molly. Ecol. Modell. 313:293-306.

Hanigan, M. D., J. A. Appuhamy, and P. Gregorini. 2013. Revised digestive parameter estimates for the Molly cow model. J. Dairy Sci. 96:3867-3885.

Hanigan, M. D., L. Crompton, C. Reynolds, D. Wray-Cahen, M. Lomax, and J. France. 2004. An integrative model of amino acid metabolism in the liver of the lactating dairy cow. J. Theor. Biol. 228:271-289. 
Hanigan, M. D., C. C. Palliser, and P. Gregorini. 2009. Altering the representation of hormones and adding consideration of gestational metabolism in a metabolic cow model reduced prediction errors. J. Dairy Sci. 92:5043-5056.

Hess, V., P. Ganier, J.-N. Thibault, and B. Seve. 2000. Comparison of the isotope dilution method for determination of the ileal endogenous amino acid losses with labelled diet and labelled pigs. Br. J. Nutr. 83:123-130.

Holder, V., J. Tricarico, D. Kim, N. Kristensen, and D. Harmon. 2015. The effects of degradable nitrogen level and slow release urea on nitrogen balance and urea kinetics in Holstein steers. Anim. Feed Sci. Technol. 200:57-65.

Huang, K. H., V. Ravindran, X. Li, and W. Bryden. 2005. Influence of age on the apparent ileal amino acid digestibility of feed ingredients for broiler chickens. Br. Poult. Sci. 46:236-245.

Lapierre, H., R. Berthiaume, G. Raggio, M. Thivierge, L. Doepel, D. Pacheco, P. Dubreuil, and G. Lobley. 2005. The route of absorbed nitrogen into milk protein. Anim. Sci. 80:11-22.

Lapierre, H., and G. Lobley. 2001. Nitrogen recycling in the ruminant: A review. J. Dairy Sci. 84:E223-E236.

Li, M. M., R. R. White, and M. D. Hanigan. 2018. An evaluation of Molly cow model predictions of ruminal metabolism and nutrient digestion for dairy and beef diets. J. Dairy Sci. 101:9747-9767.

Lin, L. I. 1989. A concordance correlation coefficient to evaluate reproducibility. Biometrics 45:255-268.

Lobley, G., and H. Lapierre. 2003. Post-absorptive metabolism of amino acids. Pages 737-756 in EAAP Publ. no. 109. W. B. Souffrant and C. C. Metges, ed. Wageningen Academic Publishers, Wageningen, the Netherlands.

Lobley, G. E., D. Bremner, and G. Zuur. 2000. Effects of diet quality on urea fates in sheep as assessed by refined, non-invasive $\left[{ }^{15} \mathrm{~N}^{15} \mathrm{~N}\right]$ urea kinetics. Br. J. Nutr. 84:459-468.

Marini, J. C., and M. Van Amburgh. 2003. Nitrogen metabolism and recycling in Holstein heifers. J. Anim. Sci. 81:545-552.

Mutsvangwa, T., K. Davies, J. McKinnon, and D. Christensen. 2016. Effects of dietary crude protein and rumen-degradable protein concentrations on urea recycling, nitrogen balance, omasal nutrient flow, and milk production in dairy cows. J. Dairy Sci. 99:62986310.

Nolan, J. V. 1975. Quantitative models of nitrogen metabolism. Page 416 in Digestion and Metabolism in the Ruminant. I. W. McDonald and A. C. I. Warner, ed. Univ. New England Publ. Unit, Armidale, Australia.

Nolan, J. V., and R. Leng. 1972. Dynamic aspects of ammonia and urea metabolism in sheep. Br. J. Nutr. 27:177-194.

NRC. 2001. Nutrient Requirements of Dairy Cattle. 7th ed. National Academy Press, Washington, DC.

Ouellet, D. R., R. Berthiaume, G. Holtrop, G. Lobley, R. Martineau, and H. Lapierre. 2010. Effect of method of conservation of timothy on endogenous nitrogen flows in lactating dairy cows. J. Dairy Sci. 93:4252-4261.

Pilgrim, A. F., F. Gray, R. Weller, and C. Belling. 1970. Synthesis of microbial protein from ammonia in the sheep's rumen and the proportion of dietary nitrogen converted into microbial nitrogen. Br. J. Nutr. 24:589-598.

Press, W. H. 2007. Numerical Recipes: The Art of Scientific Computing. 3rd ed. Cambridge University Press, Cambridge, UK.

R Development Core Team. 2015. R: A language and environment for statistical computing. http://www.R-project.org.

Rabinowitz, L., R. A. Gunther, E. S. Shoji, R. A. Freedland, and E. H. Avery. 1973. Effects of high and low protein diets on sheep renal function and metabolism. Kidney Int. 4:188-207.

Recktenwald, E. B., D. Ross, S. Fessenden, C. Wall, and M. Van Amburgh. 2014. Urea-N recycling in lactating dairy cows fed diets with 2 different levels of dietary crude protein and starch with or without monensin. J. Dairy Sci. 97:1611-1622.

Reynal, S. M., and G. Broderick. 2005. Effect of dietary level of rumen-degraded protein on production and nitrogen metabolism in lactating dairy cows. J. Dairy Sci. 88:4045-4064.
Reynolds, C., and N. B. Kristensen. 2008. Nitrogen recycling through the gut and the nitrogen economy of ruminants: An asynchronous symbiosis. J. Anim. Sci. 86(14_Suppl.):E293-E305.

Ruiz, R., L. Tedeschi, J. Marini, D. Fox, A. Pell, G. Jarvis, and J. Russell. 2002. The effect of a ruminal nitrogen (N) deficiency in dairy cows: Evaluation of the Cornell Net Carbohydrate and Protein System ruminal N deficiency adjustment. J. Dairy Sci. 85:2986-2999.

Satter, L. D., and L. L. Slyter. 1974. Effect of ammonia concentration of rumen microbial protein production in vitro. Br. J. Nutr. 32:199-208.

Smith, R. 1969. Section G. General. Nitrogen metabolism and the rumen. J. Dairy Res. 36:313-331.

Spek, J. W., A. Bannink, G. Gort, W. Hendriks, and J. Dijkstra. 2012. Effect of sodium chloride intake on urine volume, urinary urea excretion, and milk urea concentration in lactating dairy cattle. J. Dairy Sci. 95:7288-7298.

Spek, J. W., A. Bannink, G. Gort, W. Hendriks, and J. Dijkstra. 2013. Interaction between dietary content of protein and sodium chloride on milk urea concentration, urinary urea excretion, renal recycling of urea, and urea transfer to the gastrointestinal tract in dairy cows. J. Dairy Sci. 96:5734-5745.

Stevens, L. A., and A. S. Levey. 2005. Measurement of kidney function. Med. Clin. North Am. 89:457-473.

Storm, A. C., M. D. Hanigan, and N. B. Kristensen. 2011. Effects of ruminal ammonia and butyrate concentrations on reticuloruminal epithelial blood flow and volatile fatty acid absorption kinetics under washed reticulorumen conditions in lactating dairy cows. J. Dairy Sci. 94:3980-3994.

Storm, A. C., N. B. Kristensen, and M. D. Hanigan. 2012. A model of ruminal volatile fatty acid absorption kinetics and rumen epithelial blood flow in lactating Holstein cows. J. Dairy Sci. 95:2919-2934.

Titgemeyer, E. C., K. Spivey, S. Parr, D. Brake, and M. Jones. 2012 Relationship of whole body nitrogen utilization to urea kinetics in growing steers. J. Anim. Sci. 90:3515-3526.

Tran, H., A. Caprez, P. Kononoff, P. Miller, and W. Weiss. 2016. Automation of statistical procedures to screen raw data and construct feed composition databases. J. Anim. Sci. 94(Suppl. 5):681-682.

White, R. R., Y. Roman-Garcia, J. Firkins, P. Kononoff, M. VandeHaar, H. Tran, T. McGill, R. Garnett, and M. Hanigan. 2017a. Evaluation of the National Research Council (2001) dairy model and derivation of new prediction equations. 2. Rumen degradable and undegradable protein. J. Dairy Sci. 100:3611-3627.

White, R. R., Y. Roman-Garcia, J. Firkins, M. VandeHaar, L. Armentano, W. Weiss, T. McGill, R. Garnett, and M. Hanigan. 2017b. Evaluation of the National Research Council (2001) dairy model and derivation of new prediction equations. 1. Digestibility of fiber, fat, protein, and nonfiber carbohydrate. J. Dairy Sci. 100:3591-3610.

Wickersham, T., E. Titgemeyer, and R. Cochran. 2009a. Methodology for concurrent determination of urea kinetics and the capture of recycled urea nitrogen by ruminal microbes in cattle. Animal 3:372-379.

Wickersham, T. A, E. Titgemeyer, R. Cochran, E. Wickersham, and D. Gnad. 2008. Effect of rumen-degradable intake protein supplementation on urea kinetics and microbial use of recycled urea in steers consuming low-quality forage. J. Anim. Sci. 86:3079-3088.

Wickersham, T. A., E. C. Titgemeyer, R. C. Cochran, and E. E. Wickersham. 2009b. Effect of undegradable intake protein supplementation on urea kinetics and microbial use of recycled urea in steers consuming low-quality forage. Br. J. Nutr. 101:225-232.

Wohlt, J. E., J. Clark, and F. Blaisdell. 1976. Effect of sampling location, time, and method of concentration of ammonia nitrogen in rumen fluid. J. Dairy Sci. 59:459-464.

Zhu, J. S., S. Stokes, and M. Murphy. 1997. Substitution of neutral detergent fiber from forage with neutral detergent fiber from byproducts in the diets of lactating cows. J. Dairy Sci. 80:2901-2906. 